\title{
AL.2.JO
}

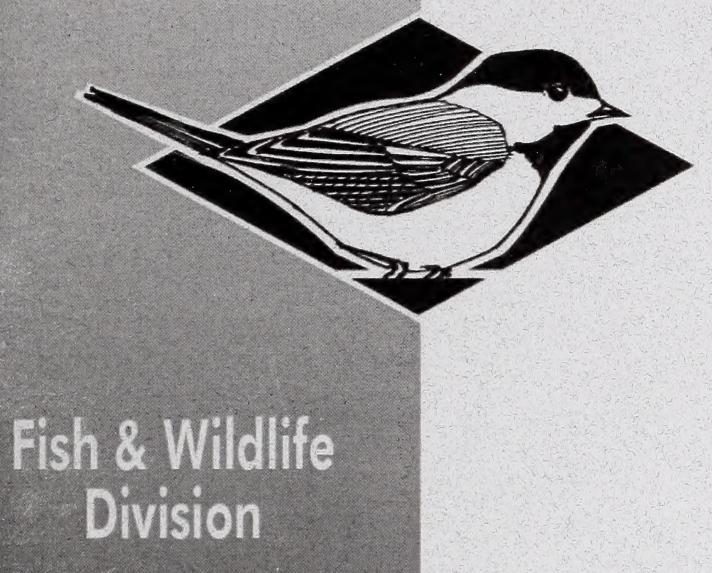

Status of the Northern Myotis

(Myotis septentrionalis) in Alberta:

Update 2009

\section{SPECIES AT RISK}

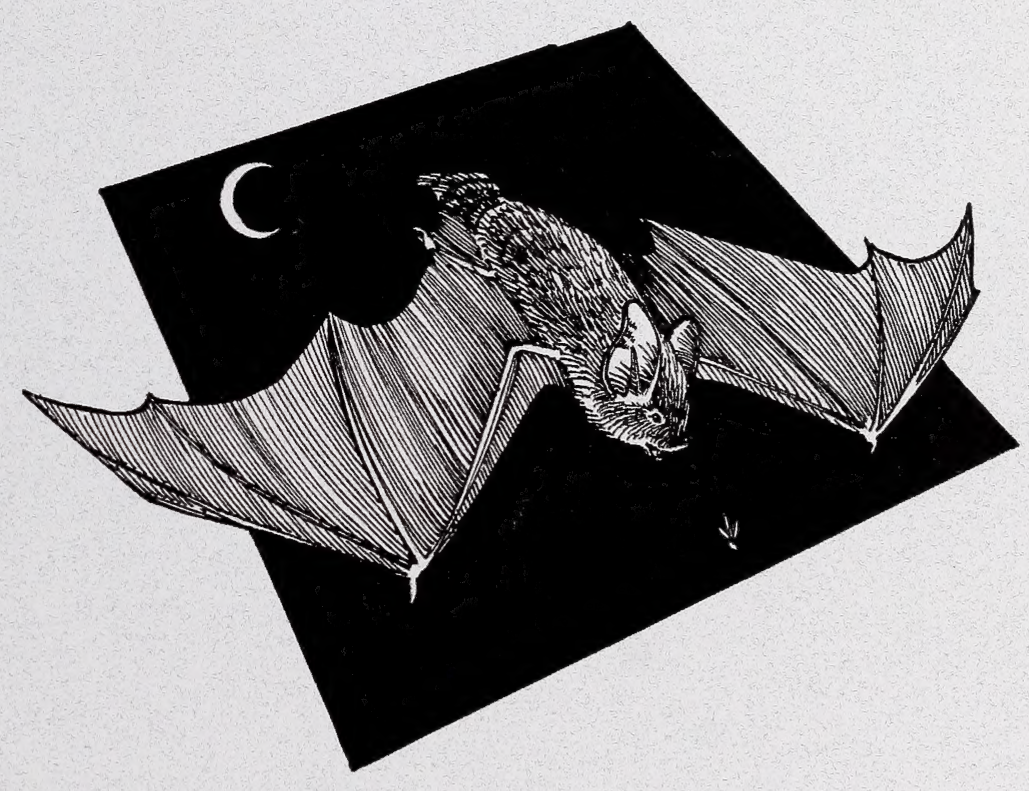

Alberta Wildlife Status Report No. 3 (Update 2009)

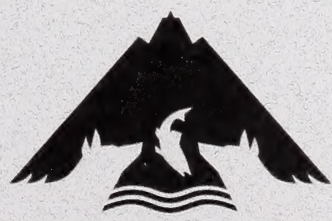

Alberta Conservation Association 


\title{
Status of the Northern Myotis (Myotis septentrionalis) in Alberta:
}

\section{Update 2009}

\author{
Prepared for: \\ Alberta Sustainable Resource Development (SRD) \\ Alberta Conservation Association (ACA)
}

\begin{abstract}
Update prepared by:
Cori Lausen

Much of the original work contained in the report was prepared by $M$. Carolina Caceres and M. J. Pybus in 1997.
\end{abstract}

This report has been reviewed, revised, and edited prior to publication.

It is an SRD/ACA working document that will be revised and updated periodically.

Alberta Wildlife Status Report No. 3 (Update 2009)

May 2009

Published By:

\section{Government of Alberta}

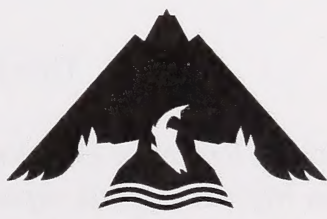

Alberta Conservation Association 
Publication No. T/214

ISBN: 978-0-7785-8474-2 (Printed Edition)

ISBN: 978-0-7785-8475-9 (On-line Edition)

ISSN: 1206-4912 (Printed Edition)

ISSN: 1499-4682 (On-line Edition)

\section{Series Editors: Sue Peters, Robin Gutsell and Gavin Berg Illustrations: Brian Huffman \\ Maps: Velma Hudson}

For copies of this report, visit our web site at: http://srd.alberta.ca/fishwildlife/speciesatrisk/ and click on "Detailed Status"

\section{$O R$}

Contact:

Information Centre - Publications Alberta Sustainable Resource Development

Main Floor, Great West Life Building 9920 - 108 Street

Edmonton, Alberta, Canada T5K 2M4

Telephone: (780) 944-0313 or 1-877-944-0313

This publication may be cited as:

Alberta Sustainable Resource Development and Alberta Conservation Association. 2009. Status of the Northern Myotis (Myotis septentrionalis) in Alberta: Update 2009. Alberta Sustainable Resource Development. Wildlife Status Report No. 3 (Update 2009). Edmonton, AB. 34 pp. 


\section{PREFACE}

Every five years, the Fish and Wildlife Division of Alberta Sustainable Resource Development reviews the general status of wildlife species in Alberta. These overviews, which have been conducted in 1991 (The Status of Alberta Wildlife), 1996 (The Status of Alberta Wildlife), 2000 (The General Status of Alberta Wild Species 2000), and 2005 (The General Status of Alberta Wild Species 2005) assign individual species "ranks" that reflect the perceived level of risk to populations that occur in the province. Such designations are determined from extensive consultations with professional and amateur biologists, and from a variety of readily available sources of population data. A key objective of these reviews is to identify species that may be considered for more detailed status determinations.

The Alberta Wildlife Status Report Series is an extension of the general status exercise, and provides comprehensive current summaries of the biological status of selected wildlife species in Alberta. Priority is given to species that are At Risk or May Be At Risk in the province, that are of uncertain status (Undetermined), or that are considered to be at risk at a national level by the Committee on the Status of Endangered Wildlife in Canada (COSEWIC).

Reports in this series are published and distributed by the Alberta Conservation Association and the Fish and Wildlife Division of Alberta Sustainable Resource Development. They are intended to provide detailed and up-to-date information that will be useful to resource professionals for managing populations of species and their habitats in the province. The reports are also designed to provide current information that will assist Alberta's Endangered Species Conservation Committee in identifying species that may be formally designated as Endangered or Threatened under Alberta's Wildlife Act. To achieve these goals, the reports have been authored and/or reviewed by individuals with unique local expertise in the biology and management of each species. 


\section{EXECUTIVE SUMMARY}

The northern myotis (Myotis septentrionalis; previously known as the northern long-eared bat) is a forest-dependent bat commonly found in eastern Canada and the United States. It is encountered less frequently in western Canada, including Alberta. At present, the northern myotis is considered May Be At Risk in Alberta. This general status designation was based on the relative rarity of this species in the province, and its apparent reliance on mature forest habitats, which are affected by current forestry practices. However, recent captures in Alberta's boreal forest bring into question whether this species may be relatively abundant in some areas of northern Alberta; further standardized survey effort across central and northern Alberta is needed to establish relative abundance, and determine if this species is widespread across its range or whether it has a patchy distribution.

The northern myotis has a broad distribution in Alberta, north of a V-shaped line extending from Wainwright to the northernmost reaches of the Red Deer River and west to Jasper. Within this area, the species is reported most often from the Boreal Forest and northern portion of the Foothills natural regions, although there are several records from the Parkland Natural Region. During the winter, the northern myotis hibernates with other bat species in caves or abandoned mines. Two hibernacula have been found in Alberta: one in a cave in Wood Buffalo National Park, and one in a cave near Cadomin.

Consistent among studies (all conducted outside of Alberta) is the tendency of this species, especially females, to roost in cracks, hollows, or under bark of deciduous trees in deciduousdominated stands; however, roosts in conifer trees are also reported, and in eastern Canada, male northern myotis tend to select roosts in coniferous trees in conifer-dominated stands. Early studies from other parts of the species' range suggested that roost trees tended to be taller and wider than what was randomly available, and that these trees were generally found in old-growth forest stands. More recent studies from other parts of its range contradict some of these findings, describing the northern myotis as more of a generalist, using roost trees of various heights and diameters, and even using remnant snags within young (under 5 years) stands. The apparent discrepancies among roosting and foraging studies suggest that either the northern myotis may be more adaptable than previously believed, or that there are extensive local variations in behaviour and ecology across this species' range, thereby necessitating study of the habitat requirements of the northern myotis in Alberta.

Factors that may limit northern myotis populations include availability and security of summer roosting and foraging habitat and of winter hibernacula, and climate change. Until summer and winter habitat requirements are known for this species in Alberta, it is unclear whether current forestry and northern development practices affect long-term population viability. Climate change is a concern to northern myotis in Alberta because of the prediction that mean tree age, and consequently tree size, in undisturbed forests will continue to decline as a result of recently documented increasing tree mortality in western North America. Another uncertainty for northern myotis is the potential spread of White Nose Syndrome into Alberta; this fungal infection causes high rates of bat mortality in hibernacula. 


\section{ACKNOWLEDGEMENTS}

For the original 1997 report prepared by M. Carolina Caceres and M. J. Pybus:

We thank R. Barclay (University of Calgary), H. Bryant and H. Smith (retired) (Provincial Museum of Alberta), L. Crampton (Boston University), A. and G. Roberts (independent consultants) and L. Wilkinson (B.C. Ministry of Environment, Lands and Parks) for information provided on captures of the northern myotis in Alberta and British Columbia. We thank D. Prescott and S. Brechtel (Alberta Natural Resources Services), H. Bryant and R. Barclay for their careful review of earlier versions of this document, D. Ryerson (Alberta Natural Resources Service) for editorial assistance and $\mathrm{J}$. Horb for producing the maps.

\section{For the $\mathbf{2 0 0 9}$ update prepared by Cori Lausen:}

We thank R. Barclay (University of Calgary), S. Peters (Alberta Conservation Association; ACA), G. Berg (Alberta Sustainable Resource Development; ASRD), and R. Gutsell (ASRD) for editorial comments, and V. Hudson (ACA) for producing the maps. For information provided on captures of the northern myotis, we thank R. Barclay, D. Player (Matrix Solutions), S. Grindal (Axys Consulting/Conoco Phillips), C. Stefan (Golder Associates), N. McDonald (Golder Associates), C. Godwin-Sheppard (Amec Consulting), L. Burt (Westworth and Associates), K. Patriquin (University of Calgary), B. Hamilton (TAEM Consulting), D. Hobson (ASRD), D. Vujnovic (Alberta Natural Heritage Information Centre), and L. Blythe (ASRD); and for additional information or capture data outside of Alberta, we thank D. Nagorsen (Mammalia Consulting), T. Luszcz (University of Calgary), T. Jung (Yukon Government, Department of Environment; Yukon Mammal Technical Advisory Committee Chair), and D. Blehert (U.S. Geological Survey, National Wildlife Health Centre).

Preparation of this report was funded by the Alberta Conservation Association and the Fish and Wildlife Division of Alberta Sustainable Resource Development. 
Digitized by the Internet Archive in 2016 


\section{TABLE OF CONTENTS}

PREFACE iii

EXECUTIVE SUMMARY iv

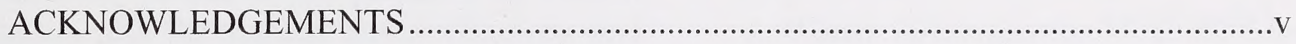

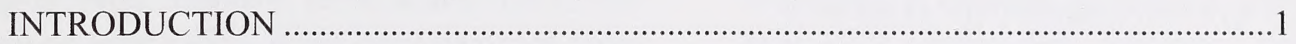

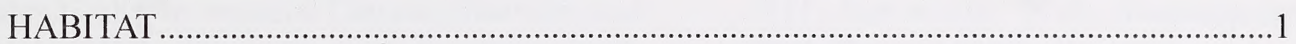

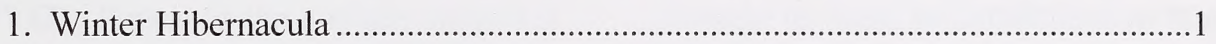

2. Summer Roosting and Foraging Habitat ..........................................................

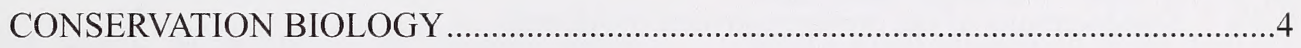

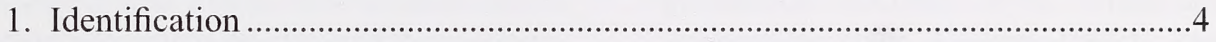

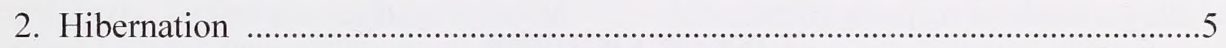

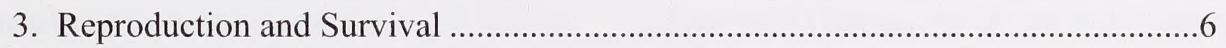

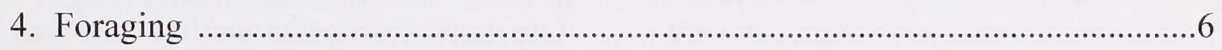

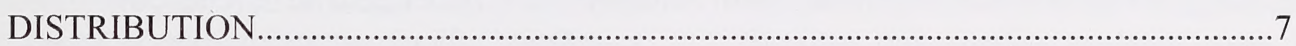

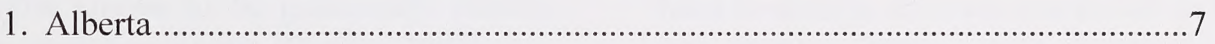

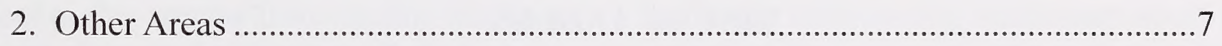

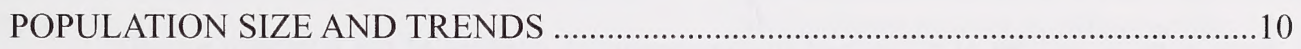

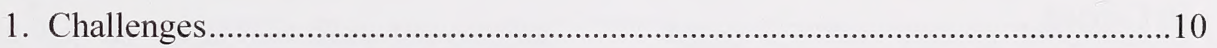

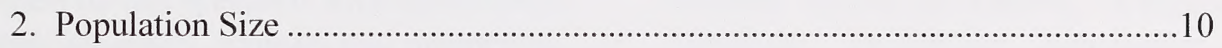

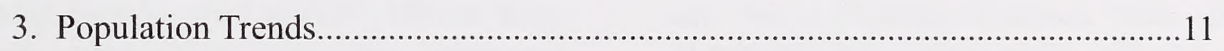

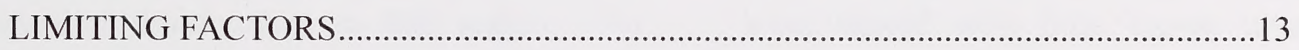

1. Availability of Summer Roosting Habitat ………………………......................13

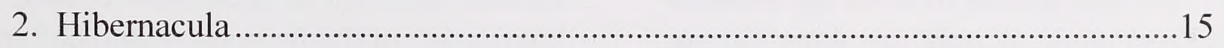

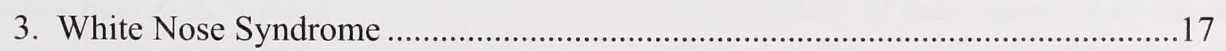

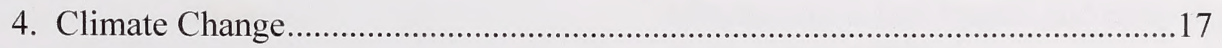




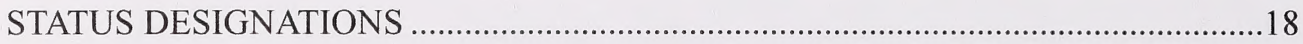

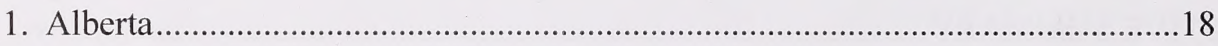

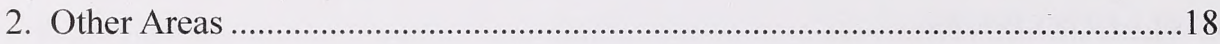

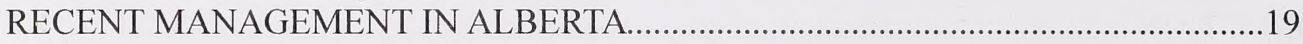

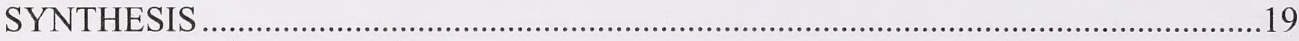

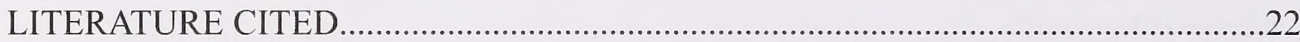

APPENDIX 1 Definitions of status ranks and legal designations ....................................31

APPENDIX 2 Site locations of the northern myotis in Alberta..........................................33

\section{LIST OF FIGURES}

Figure 1 Site records and presumed distribution of the northern myotis in Alberta............8

Figure 2 Range of the northern myotis in North America ................................................

\section{LIST OF TABLES}

Table 1 Summary by region of published studies reporting capture of the northern myotis in Canada. 


\section{INTRODUCTION}

The northern myotis (Myotis septentrionalis; previously known as northern long-eared bat, Wilson and Reeder 2005) is found in many regions of Canada. Although there are numerous records of its presence in eastern Canada and the United States (Barbour and Davis 1969, Dobbyn 1994, Kurta 1995, van Zyll de Jong 1985), it has been recorded more sporadically in western Canada (Barbour and Davis 1969, Nagorsen and Brigham 1993, Smith 1993). Presently, the northern myotis is considered May Be At Risk* in Alberta (Alberta Sustainable Resource Development 2007).

This report, an update of the original status report (Caceres and Pybus 1997), summarizes information relevant to the status of the northern myotis in Alberta. Before proceeding, it should be noted that prior to 1980 , the northern myotis was considered to be a subspecies of M. keenii and was occasionally referred to as "Keen's bat," or the "eastern long-eared bat" (Fitch and Shump 1979, van Zyll de Jong 1979). Presently, M. keenii is restricted to the Pacific Northwest and is now known to be genetically distinct from the northern myotis (Dewey 2006); any references to this species from outside that area refer to M. septentrionalis (van Zyll de Jong 1979).

It should also be noted that since the original status report for this species (Caceres and Pybus 1997) was published, acoustic and mistnetting surveys of bats in northeastern Alberta have increased, coinciding with the increased industrial development in that region. No habitat studies have been done on this species in Alberta; therefore, several roost selection studies done in other parts of its range provide our only foundation upon which to understand this species' habitat in Alberta.

* See Appendix 1 for definitions of selected status designations.
Habitat selection by the northern myotis can be divided into two major components: 1) winter hibernacula; and 2) summer roosting and foraging habitat.

1. Winter Hibernacula. - The northern myotis hibernates in caves or abandoned mines (Caire et al. 1979, Griffin 1940, Hitchcock 1949, Mills 1971, Schowalter 1980, Swanson and Evans 1936, Thomas 1995). Swarming and mating are thought to occur in the vicinity of hibernacula prior to hibernation (Caceres and Barclay 2000). Within a cave, northern myotis generally occurs with other species of bats, but is thought to form a small proportion of the total hibernating population (Griffin 1940, Hitchcock 1949, Schowalter 1979, Thomas 1993). The largest hibernating group of northern myotis in Canada was approximately 300 individuals in a cave in Quebec (Thomas 1993); in this hibernaculum, northern myotis made up approximately $25 \%$ of the total number of hibernating bats. Northern myotis may be overlooked in a hibernaculum because this species tends to roost in deep, hard-to-sample crevices (reviewed in Caceres and Barclay 2000). It is, however, unclear whether this roosting behaviour would result in gross under-estimates of the relative abundance of northern myotis in hibernacula.

There are two known hibernacula used by northern myotis in Alberta: Cadomin Cave $\left(53^{\circ} 00^{\prime} \mathrm{N}\right.$; $117^{\circ} 20^{\prime} \mathrm{W}$; Schowalter 1980), and Wood Buffalo National Park $\left(60^{\circ} 00^{\prime} \mathrm{N}\right.$; $114^{\circ} 00^{\prime} \mathrm{W}$; Schowalter 1979). The hibernacula were shared with little brown myotis $(M$. lucifugus) and long-legged myotis ( $M$. volans), but specific site preferences within the hibernacula differed among species. Northern myotis made up zero to three percent of the total number of bats collected at any one time at these sites. In Alberta, bats often reach the hibernacula in late August and early September (Schowalter 1980). 
In general, bats choose hibernaculum sites that provide a relatively constant, low $\left(0^{\circ}\right.$ to $\left.4^{\circ} \mathrm{C}\right)$ temperature with high humidity and no air currents. Within these sites, northern myotis usually hang singly in small narrow crevices (Caire et al. 1979, Kurta 1995). Anecdotal evidence suggests that northern myotis prefer moister and cooler sites (caves/mines or regions of a cave/mine) than little brown myotis in the same hibernaculum (Barbour and Davis 1969, Hitchcock 1949).

\section{Summer Roosting and Foraging Habitat. -}

Across its range, northern myotis uses a variety of tree species for roosting (Owen et al. 2002), suggesting it is not the tree species but rather the physical and microclimatic characteristics that dictate roost selection (Chung-MacCoubrey 2005). Mature forest stands provide important roosting habitat for this species (Vonhof and Wilkinson 1999); however, the exact tree characteristics selected by this species are unclear. Characteristics of trees used as roost sites in Alberta have not been investigated, and studies elsewhere have produced mixed results regarding roost tree selection. In general, this species is dependent on forests, foraging and commuting in the forest interior (Broders et al. 2006, Carter and Feldhamer 2005, Jung et al. 1999, Lacki and Hutchinson 1999, Owen et al. 2003, Patriquin and Barclay 2003), but also commuting along edge habitats, rarely (if ever) flying through open non-forested areas (Henderson 2007, Hogberg et al. 2002).

Roosting occurs only in intact forest (i.e., forest interior), and unlike most other species of treeroosting bat, northern myotis select roost trees with a higher degree of canopy cover (stem density, vegetative clutter) than around potential roost trees (Foster and Kurta 1999, Menzel et al. 2002, Owen et al. 2002). This is likely because of their great agility (reviewed in Caceres and Barclay 2000). This species' ability to glean insects from vegetation, in addition to aerial hawking of prey, makes them well adapted for forest interior foraging (Ratcliffe and Dawson
2003), and has likely resulted in their apparent dependency on intact forests. Henderson and Broders (2008) determined that northern myotis do not fly more than $78 \mathrm{~m}$ from an edge of intact forest, thereby avoiding open, unforested areas. In general, cavity-roosting bats select roost trees based on proximity to water (KalcounisRüppell et al. 2005). In Illinois, during the driest periods, roosts of northern myotis were within $750 \mathrm{~m}$ of a source of fresh water (Carter and Feldhamer 2005).

Northern myotis have been found roosting in crevices behind peeling bark, cavities in partially decayed trees, or cracks in trees (Carter and Feldhamer 2005, Clark et al. 1987, Foster and Kurta 1999, Menzel et al. 2002, Mumford and Cope 1964, Vonhof et al. 1997). While some studies report use of mainly dead trees (Broders and Forbes 2004, Menzel et al. 2002, Sasse and Pekins 1996), others report equal use of dead and living trees (Carter and Feldhamer 2005, Foster and Kurta 1999). Roosts in mid-decay stages have frequently been reported (Broders and Forbes 2004, Lacki and Schwierjohann 2001). Northern myotis has been shown repeatedly to select roosting areas containing a high density of snags (Owen et al. 2002); this is especially true for females roosting in colonies (Lacki and Schwierjohann 2001). Solitary-roosting individuals show greater flexibility, roosting in living trees more often than colonial-roosting individuals (Lacki and Schwierjohann 2001).

Early roosting studies of northern myotis found that tall, wide-diameter, partially dead trees with a high percentage of the bark remaining are favoured over other seemingly suitable trees (Caceres 1998, Sasse and Pekins 1996), corroborating studies of other tree-roosting bats (Kalcounis-Rüppell et al. 2005, Vonhof and Barclay 1996). However, more recent roosting studies on this species report that researchers are unable to discriminate between roost trees and potential roost trees (those with at least one cavity and/or of minimum diameter at breast- 
height [dbh]; Foster and Kurta 1999, Vonhof et al. 1997). Roost trees are not always tall, with roosts as low as $1 \mathrm{~m}$ from the ground (Cryan et al. 2001). Unfortunately, all of these roosting studies have occurred in areas substantially south of northern Alberta, where roosting conditions are inevitably different because of climate. It is therefore difficult to extrapolate any of these results to the roost preferences of northern myotis in northern Alberta.

A sex-specific roosting study in eastern Canada (Broders and Forbes 2004) documented males roosting in smaller trees (mean dbh $32.0 \pm 1.6 \mathrm{SE}$ ), whereas females typically roosted in cavities of trees with larger dbh (mean dbh $43.8 \pm 1.8 \mathrm{SE}$ ). In general, it has been determined that females tend to roost in groups in mature, shadetolerant deciduous stands (Broders and Forbes 2004; Foster and Kurta 1999; Menzel et al. 2002; Sasse and Pekins 1996), whereas males typically roost solitarily in either deciduous or coniferous trees (Broders and Forbes 2004; Ford et al. 2006; Jung et al. 2004; Lacki and Schwierjohann 2001). Although coniferous trees appear to be important to male northern myotis, conifer trees are rarely selected as roosts by females (Broders and Forbes 2004, Henderson et al. (2008).

Warm roosts are particularly important to reproductive females and juveniles. It is likely that adult female northern myotis, like other bats, use torpor (body cooling) to a lesser extent during reproduction in order to maximize fetal development and milk production (Racey 1973, Wilde et al. 1999). Newborn Myotis bats grow rapidly and generally begin flying within a month after their birth (Fenton 1983). Maximum energy is directed toward growth, and a maternity roost that maintains a warm microclimate will maximize juvenile growth and development (Humphrey et al. 1977). Roosts may be selected based on microclimate to meet thermoregulatory requirements during reproduction (e.g., Lausen and Barclay 2003). Given that northern myotis roosts tend to be lower in the canopy, and in more cluttered (i.e., dense or structurally complex vegetation) and thus more shaded sites than are typical for many other tree-roosting species, it has been suggested that solar radiation may be a less important roost criterion than it is for other bat species (Menzel et al. 2002). Unfortunately, no thermoregulatory studies have been done on this species to know whether their patterns of torpor and roost microclimate selection differ from other species. In the Greater Fundy area of New Brunswick, northern myotis consistently give birth several weeks later than building-roosting little brown myotis in the area (Broders et al. 2006). This may reflect roost microclimate, and suggests differences in selection pressure and perhaps reproductive success between the two species (Broders et al. 2006, Lausen and Barclay 2006b).

Individual northern myotis move between a number of roost trees, switching every two days on average (Foster and Kurta 1999), although they seem to switch less often during lactation (every 5 days on average; Menzel et al. 2002). Roosts can be within a few hundred metres of each other (Crampton 1995, Vonhof and Barclay 1996), but consecutive roosts up to $2 \mathrm{~km}$ apart have been reported (Foster and Kurta 1999). Females have been found to have roosting and foraging ranges that are 6.1 and 3.4 times larger, respectively, than those of males (Broders et al. 2006).

Although earlier capture records suggested this species was dependent on mature or oldgrowth forest stands (as summarized in Caceres and Pybus 1997), more recent widespread capture efforts in Alberta and elsewhere have found northern myotis also in young stands and disturbed forest regimes (Crampton and Barclay 1998, Cryan et al. 2001, Foster and Kurta 1999, Henderson and Broders 2008, Henderson et al. 2008, Lausen 2006a, Menzel et al. 2002). In disturbed landscapes, such as an agriculture-forest mosaic, this species has been found in remnants of intact forest, 
provided minimum woodlot sizes are retained. Minimum forest fragment sizes for Prince Edward Island have been established (see Limiting Factors - Summer Roosts for further details; Henderson et al. 2008), but no such study has taken place in western Canada. In a fragmented forested landscape, foraging range sizes for female northern myotis are substantially smaller $(9 \%-13 \%$ of the foraging ranges of northern bats in intact forest; Broders et al. 2006, Henderson 2007, Owen et al. 2003). It is likely that population density decreases in patchy landscapes in response to limited roosts and foraging opportunities; however, population density is difficult to measure. In Alberta, smaller intact forest fragments have been associated with less bat activity than have larger blocks of forest retention (Marinelli 2000). Although reduced mobility and home range sizes have been studied in fragmented forest environments, no attempt has been made to understand population size and changes in bat density in relation to these landscape disturbances.

Presumably, this species has evolved with a natural disturbance regime. Historically, fire has created a mosaic of forest habitat patches, leaving live and dead trees in clumped patches (Hansson 1992, EMEND 2006). After small patches of forest burn, local shifts in bat foraging and roosting behaviour are likely to occur in response to available habitat (Patriquin and Barclay 2003).

Reproductive female northern myotis may gather in various-sized colonies, showing some degree of social organization (evidence of nonrandom sub-groupings of the colony; Garroway and Broders 2007). Maternal colonies may be in buildings (Barbour and Davis 1969, Brandon 1961, Henderson and Broders 2008), or in cavities in trees; mean colony size in Michigan was reported to be $17 \pm 2$ bats ( $n=$ 65 observations; Foster and Kurta 1999), with colonies as large as 88 in West Virginia (Owen et al. 2002). Most males or non-reproductive females roost singly or in small $(<10)$ groups in trees; however, they may also roost in or on buildings, or in caves or other available crevices (reviewed in Caceres and Barclay 2000). The relative importance of human-made structures for day roosts for northern myotis in Alberta is unknown. The only putative building-roosting colonies of this species were reported by Vujnovic (2001); however, genetic evidence post-reporting has since revealed an error in species identification; the building-roosting northern myotis reported in Vujnovic (2001) are in fact little brown myotis (D. Vujnovic, pers. comm.). Genetic species confirmation together with thorough morphological quantification of building-roosting Myotis from central and northern Alberta is encouraged to better document building-roosting colonies of bats in the province.

\section{CONSERVATION BIOLOGY}

1. Identification. - The northern myotis is one of five species of Myotis that occur in Alberta. The species is most likely to be confused with the little brown myotis or the long-eared myotis (M. evotis), but can sometimes be distinguished from these species on the basis of ear length (14 mm - $19 \mathrm{~mm}$ versus $9 \mathrm{~mm}-17 \mathrm{~mm}$ and $17 \mathrm{~mm}-22 \mathrm{~mm}$ in the little brown myotis and the long-eared myotis, respectively; Nagorsen and Brigham 1993). Unfortunately, ear length is a difficult measurement to make correctly (ruler placed along the lateral edge inside the pinna and carefully but firmly rooted in the basal part of the ear), and even measurements made on the same animal by different observers can differ by several mm (D. Nagorsen and C. Lausen, unpubl. data). Even with accurate pinna measurements, ear length overlap among the species can preclude conclusive species identification based on this morphological trait alone. In northern Alberta, tragus (small pointed projection in the middle of the external ear) shape, absence of dark face-mask, subtle membrane/fur colour contrast, and presence of a keeled calcar (spur of cartilage arising 
from the inside of the ankle) can assist in identifying northern myotis. Although little brown myotis can have long ears (Nagorsen and Brigham 1993), the tragus is generally blunt, wide and often lobular in shape. This is in contrast to northern myotis, which have a narrow triangular-shaped tragus that ends in a relatively sharp point (D. Nagorsen and C. Lausen, unpubl. data). Additionally, northern myotis tend not to have obvious masks across their eyes and their brown fur colour does not sharply contrast with their brown membranes; this differs from the long-eared myotis, which have obvious masks and dark brown pinnae and membranes (pinnae of long-eared myotis tend to be very glossy), contrasting sharply against their pale pelage (Nagorsen and Brigham 1993, van Zyll de Jong 1985). Finally, although not always present, a very small keel (triangular flap of tissue) can sometimes be found on one or both calcars of northern myotis, aiding in their differentiation from little brown myotis (Lausen et al. 2008).

Northern myotis, although morphologically similar to other Myotis in Alberta, are genetically distinct, with mitochondrial DNA sequences that show high levels of divergence from other Alberta Myotis (Dewey 2006). As such, the only definitive way to differentiate this bat from other similar species is through genetic analysis.

It has been hypothesized that northern myotis have been misidentified as little brown myotis for many years in northern Alberta (K. Patriquin, pers. comm.). Genetic sampling is now allowing for conclusive identification of northern myotis; Grindal et al. (submitted) found that $86 \%$ and $83 \%$ of recent field identifications of little brown myotis and northern myotis, respectively, by experienced bat biologists were correctly identified in the field when verified by genetic testing. This confirms that error in field identification has taken place, and suggests that biologists less experienced with bat identification may have made substantial misidentifications of these species in past surveys.

The average size reported for the northern myotis is $7.4 \mathrm{~g}$ with forearm length of $36.4 \mathrm{~mm}$ (van Zyll de Jong 1985). Females tend to be slightly larger than males. In addition, a fullterm fetus may add up to $25 \%$ to the body mass of a pregnant female. However, size is a highly variable characteristic and adult northern myotis as small as $5 \mathrm{~g}$, with a $34-\mathrm{mm}$ forearm, have been caught (Nagorsen and Brigham 1993, M. C. Caceres, unpubl. data).

It is difficult to differentiate little brown myotis, northern myotis, and long-eared myotis in flight, because their echolocation calls broadly overlap at approximately $40 \mathrm{kHz}$ (Fenton et al. 1983). Although there are some features of the call sonogram that can allow the species to be differentiated in some cases, overlap of call characteristics will result in an under- or over-estimate of the species, depending on the rule-set employed (C. Lausen, unpubl. data). This is most relevant when analyzing zero-crossing data (sonograms as recorded by the Australian-made Anabat detector [Titley Electronics]), given that sound amplitude is not recorded (amplitude is recorded with other types of ultrasonic detectors such as Pettersson time expansion units [Pettersson Electronik, Sweden], although these units are currently not well suited for passive monitoring).

2. Hibernation. - Female Myotis bats begin visiting their hibernaculum between August and early October. Suitable hibernaculum sites have a narrow range of environmental conditions and thus bats may have to travel long distances to reach an appropriate site. Although the distance travelled between the summer habitat and the hibernaculum site is generally not known, banding recoveries indicate that some little brown myotis that summer in northcentral Alberta travel to the Cadomin area to hibernate (Fish and Wildlife Division, unpubl. data). It seems reasonable to assume that 
northern myotis also may travel long distances to reach their hibernacula; the longest distance reported for this species between summer and hibernating areas in B.C. is $56 \mathrm{~km}$ (Nagorsen and Brigham 1993).

Male and female Myotis spp. return to the same hibernaculum year after year. Some little brown myotis banded in Cadomin Cave in the late 1970s (Schowalter 1980) have been recaptured or resighted as recently as 2009 (D. Hobson, pers. comm.).

Swarming and mating in Myotis spp. occur in the fall, generally at the hibernaculum site. Females then store sperm over the winter, and a single egg is fertilized when the female arouses from torpor and leaves the hibernaculum in the spring (Racey 1982). Gestation (fetal development) is approximately 60 days and birth occurs in late June and July (van Zyll de Jong 1985).

During summer, bats must accumulate enough resources to maintain the high metabolic costs associated with flight and reproduction; in late summer and fall, they feed to gain sufficient fat reserves for winter hibernation. Female bats must accumulate greater energy reserves than males in order to produce and care for the offspring (Barclay 1991). Lactating females need adequate food to meet their own energy needs as well as to produce milk for the pup. Canadian species of Myotis generally add $30 \%$ to $40 \%$ of their summer mass in fat to use as energy reserves during hibernation (Nagorsen and Brigham 1993, Thomas et al. 1990).

\section{Reproduction and Survival. - Unlike} other small mammals, all North American Myotis spp., including the northern myotis, are relatively long-lived. The record age of a northern myotis in the wild is 18.5 years (Hall et al. 1957). Also in contrast to most small mammals, each female bat produces only one offspring each year. Although anecdotal records of predation on bats have not included the northern myotis, it is likely that owls, magpies, and snakes prey upon them occasionally, as these are predators on other bats in Alberta.

Environmental conditions influence the ability of a female bat to successfully raise an offspring in any given season. When conditions such as high rainfall, cold weather, or windy evenings reduce insect availability, females may not be able to gather enough food; this can delay growth of offspring, and if it occurs in spring, it may cause females to delay or forego reproduction entirely for that season (Grindal et al. 1992). Most mortality in North American bat species occurs in the juvenile age class and many pups do not survive their first year (Tuttle and Stevenson 1982). Additional mortality occurs during the hibernation period. If winters are harsh, or if bats cannot obtain the fat reserves necessary to survive this period, they may starve. Juveniles are particularly vulnerable during hibernation because they have a relatively short time after their birth to build up fat reserves (Nagorsen and Brigham 1993). Especially in northern climates where the growing season is short, delayed parturition could have a negative impact on pups' first-year survival; little is known about reproductive patterns and survival rates in the northern distribution of most bats. Reproductive data are not housed in the provincial database (Alberta Fish and Wildlife Management Information System), therefore, the age of first reproduction and reproductive rates of northern myotis females in Alberta are unknown. Other temperate bat species generally reproduce when they are one or two years of age (Altringham 1996).

4. Foraging. - Like all bat species in Canada, the northern myotis feeds exclusively on insects. Myotis bats are generalist insectivores, and their diet is limited by the size, behaviour, and quality (e.g., carapace hardness) of the insects they are capable of catching. Although moths and beetles make up the majority of the diet of Myotis spp., mosquitoes, black flies, and other species considered to be pests also 
are consumed. Generally, northern myotis uses various food items, including species of Hemiptera (true bugs), Lepidoptera (moths), Hymenoptera (bees and wasps), Diptera (flies), and Homoptera (includes leafhoppers and aphids; van Zyll de Jong 1985).

Within the group of Myotis bats, differences in foraging strategy (Fenton 1990, Fenton and Bell 1979) have evolved to reduce overlap and competition. Most insectivorous bats feed on flying insects (these bats are called "hawkers"). Other bats (known as "gleaners") use passive listening as well as echolocation to locate and capture insects resting on leaves, tree trunks or against buildings. This technique is an apparent foraging advantage in cooler conditions when the abundance of flying insects is reduced (Taylor 1963). Northern myotis are opportunistic and will hawk insects from the air or glean prey from substrates (Ratcliffe and Dawson 2003).

\section{DISTRIBUTION}

1. Alberta. - In Alberta, the northern myotis is most often reported in the Boreal Forest Natural Region, and the northern section of the Foothills Natural Region (Figure 1, Appendix 2; Alberta Natural Heritage Information Centre 2006). Northern myotis have been captured at Cadomin Cave (Schowalter 1979, H. Smith, pers. comm.), and 16 of 30 northern myotis specimens in the Provincial Museum of Alberta were collected at this site. There also are limited records from the Peace River Parkland and Central Parkland subregions. Most recently, a large number of captures have been made in the oil sands area near Fort McMurray (Figure 1, Appendix 2).

It is not clear from the capture data for Alberta whether northern myotis is evenly distributed across the northern part of the province, but it is likely scattered across the Boreal Forest Natural Region, and at least some of the Parkland and Foothills natural regions (Figure 1). Given that bats tend to be selective in the micro-habitats they occupy (e.g., particular roost conditions are selected within forest stands), and that the Boreal region is not uniformly composed of suitable roost trees, local distributions are probably patchy. Therefore, local concentrations of northern myotis, such as those documented during extensive sampling in the oil sands area near Fort McMurray (S. Grindal, pers. comm.) are likely to reflect pockets of suitable habitat; this relative abundance of northern myotis may not be representative of the entire Alberta distribution of northern myotis. As expected, based on percent forest cover, this species is far less common in the Parkland region compared to the Boreal region.

The area of occupancy of northern myotis is $132 \mathrm{~km}^{2}$. This reflects the area summation of $2 \mathrm{~km} \times 2 \mathrm{~km}$ squares that have had mistnet sampling within them, with at least one northern myotis being captured (or in the case of museum records, at least one voucher being taken). The extent of occurrence is $357026 \mathrm{~km}^{2}$, representing the area of the polygon encompassing all known records. For this latter calculation, potentially unoccupied and unsuitable habitats may be included.

2. Other Areas. - The northern myotis is found across the southern forested regions of Canada (except in B.C.; Figure 2), but is captured more frequently in eastern Canada and the United States than in western Canada. Records of this species in western regions are on the rise and may reflect increased survey efforts and/ or an increased ability to distinguish northern myotis from other similar Myotis. As more widespread inventory efforts continue, and genetic identification of captures becomes more common, accurate distribution maps and relative abundance estimates will follow.

The species has been found regularly in southern Ontario, southern Quebec, and in the Maritime provinces, as well as in eastern regions of the United States (Dobbyn 1994, Godin 1977, 


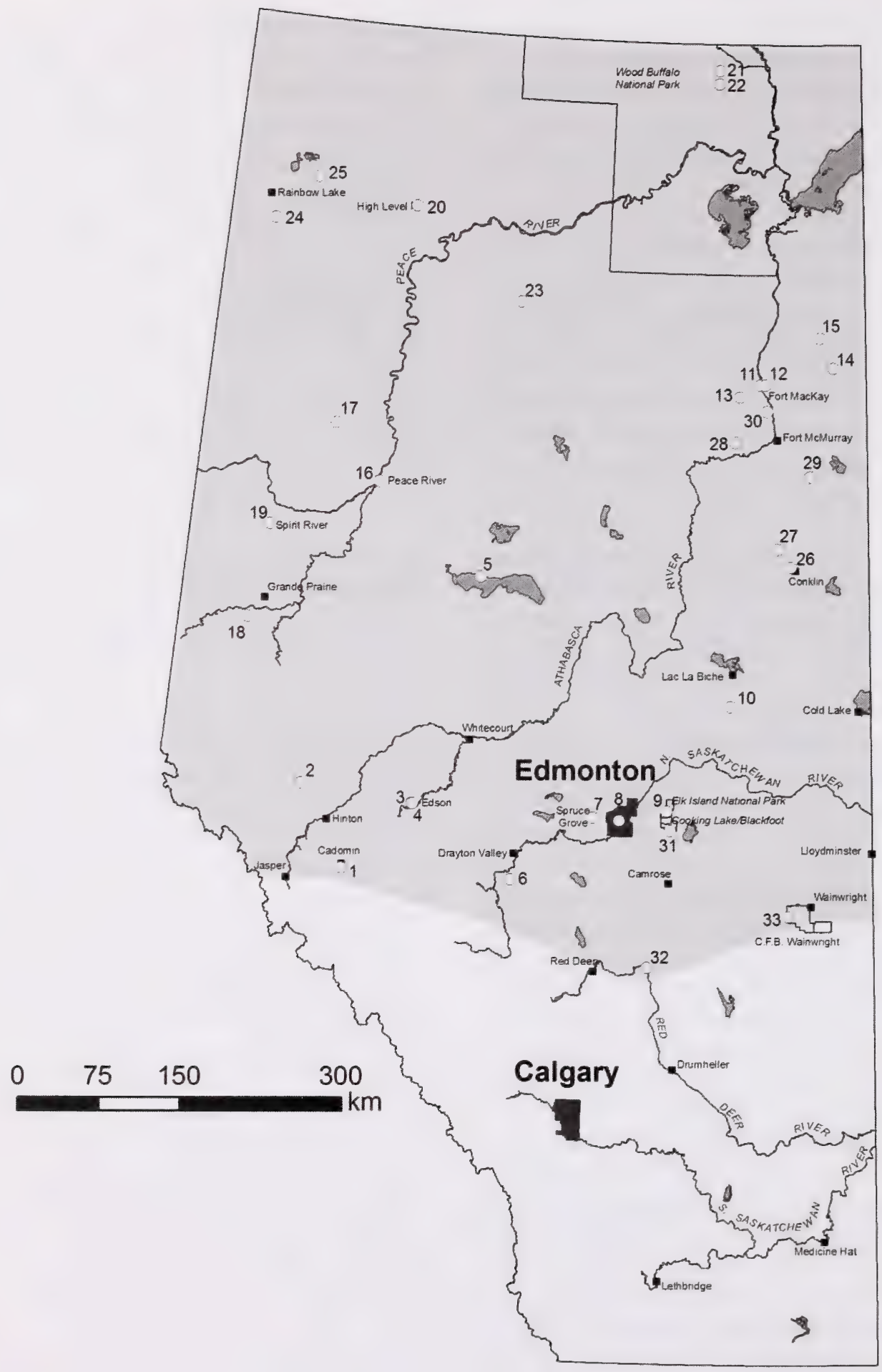

Figure 1: Site records and presumed distribution of the northern myotis in Alberta. Numbered sites are described in Appendix 2. 


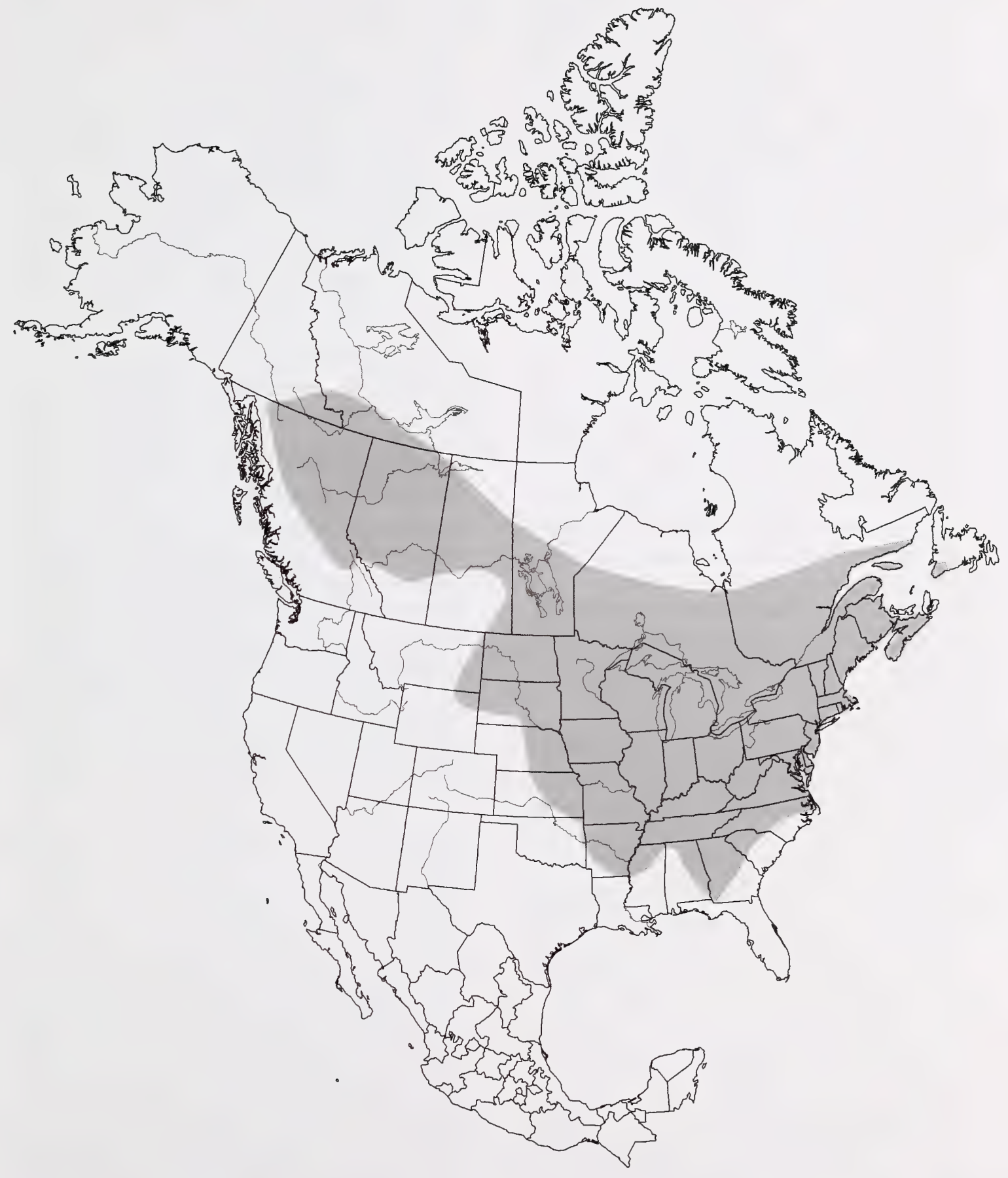

Figure 2: Range of the northern myotis in North America (adapted from Caceres and Barclay 2000). 
Hamilton and Whitaker 1979, Thomas 1993, van Zyll de Jong 1985). The range of the northern myotis in the United States extends from the Canadian border south to northern Florida (Rice 1955) and west into North Dakota, South Dakota, Nebraska, and Wyoming (Knox Jones et al. 1983, Turner 1974). In Canada, the documented range of the northern myotis extends north into central Quebec, and northern parts of Ontario, Manitoba, Saskatchewan, and Alberta, as well as the southwest corner of the Northwest Territories and the southeast corner of the Yukon (Jung et al. 2006, Lausen 2006b, Lausen et al. 2008, Nagorsen and Brigham 1993, Nagorsen and Nash 1984, Smith 1993, van Zyll de Jong 1985, Wrigley 1974). Currently the western boundary of the range appears to be the Coastal Mountains in northern British Columbia, and the west slope of the Rocky Mountains in more southern reaches of B.C. (near Revelstoke, B.C.; van Zyll de Jong et al. 1980, B.C. Ministry of Environment 2008).

Overall, the known range of the northern myotis is primarily restricted to forested regions, with a distinct avoidance of the prairies, coastal rainforests, and southern Rockies. Occasionally, northern myotis is captured in the central plains of the United States, but these situations occur in forest remnants or in caves used for hibernation (Turner 1974). Henderson et al. (2008) reported loss of forest cover and specifically the loss of deciduous stands to be limiting the distribution of northern myotis in eastern Canada; on Prince Edward Island the northern myotis is restricted to remnant fragments of forest of sufficient size with sufficient tree cover and percentage of deciduous trees.

\section{POPULATION SIZE AND TRENDS}

1. Challenges. - The life history of bats (i.e., low reproductive rates, high overwinter juvenile mortality; Barclay et al. 2004) makes their populations vulnerable to declines, and therefore being able to monitor trends in populations of bats is highly desirable (O'Shea and Bogan 2003). Estimates of population size of northern myotis are hampered by the fact that the species is a forest-dwelling bat that is difficult to detect. Because this bat tends to forage in the forest interior, mistnet surveys must target cluttered areas; northern myotis are less likely to be captured over water than are little brown myotis, requiring different mistnetting strategies than are used to catch other myotis (Broders et al. 2006, Jung et al. 1999). Similarly, acoustic surveys must place detectors on both forest edges and in the forest interior rather than in clearings near open water bodies to increase the chances of recording northern myotis. Even then, acoustic recordings will usually under-represent this species (Broders et al. 2003) because of the low intensity ultrasound produced by this bat compared to other species (Faure et al. 1993). Although some species of bats in northern Alberta are detected and recorded by bat detectors up to $40 \mathrm{~m}$ away from a bat, northern myotis generally must approach within a few metres of the detector microphone to be recorded (C. Lausen, pers. obs., D. Nagorsen, pers. comm.). In northern Alberta, echolocation calls of northern myotis overlap with those of little brown myotis (Broders et al. 2004), further limiting the ability to gather information about this species from acoustic recordings.

\section{Population Size. - Although capture numbers} for northern myotis have been increasing over recent years as a result of increased bat inventory efforts in the north, especially in the northeast in conjunction with industrial developments, it is impossible to estimate the provincial population size of the northern myotis. Survey efforts in the oil sands area near Fort McMurray have led some biologists doing work in this area to suggest this species, which is abundant in relation to other northern bat species in this region, is relatively more abundant than previously believed (Grindal et al. submitted). However, many confounding variables prevent these data from being useful in understanding relative abundance of northern myotis in 
northeastern Alberta. Mistnetting efforts vary highly among bat biologists doing work in this region, with those using high nets strung across relatively large seismic cutlines producing a lower capture ratio of northern myotis than those using lower nets strung in more cluttered intact forest where few, if any, other northern Alberta bat species tend to forage (C. Lausen, pers. obs., D. Player, pers. comm.). This bias in mistnetting effort can have dramatic effects on relative species abundances in an area. For example, two mistnetting surveys that took place in southwest B.C. in exactly the same netting locations (sites were within metres of each other), each for two years (one survey: 2000 and 2001; subsequent survey: 2007 and 2008), resulted in 76 bat captures in 2000 and $2001,10.5 \%$ of which were species of longeared bats (either Keen's myotis or long-eared myotis); yet in 2007 and 2008, 42.9\% of 63 captures were long-eared species (T. Luszcz, unpubl. data, C. Lausen and D. Nagorsen, unpubl. data). The difference between these two survey efforts was that in 2007 and 2008, long-eared bat species were targeted and thus nets were placed lower and among more clutter than in 2000 and 2001.

Other confounding factors in understanding northern myotis abundance and distribution in northern Alberta is that most northern myotis and little brown myotis captures have not been genetically confirmed, leaving room for error in species identification. It is also common practice to mistnet survey areas within proposed development sites that are likely to provide good foraging/roosting opportunities for the only bat of conservation concern in northern Alberta, the northern myotis (May Be At Risk; Alberta Sustainable Resource Development 2007); in other words, targeting older deciduous stands in close proximity to water (C. Lausen, pers. obs.). As such, it is impossible to evaluate to what extent, if any, northern myotis occur outside of these targeted optimal habitat patches. It is also possible that targeting northern myotis (low nets in cluttered forest or narrow seismic/cutlines) could produce a capture ratio for bat species representative of habitat that is optimal for northern myotis, thus under-representing the other bat species in northern Alberta, which do not typically glean prey and as such are more open- and/or high-flying species (little brown myotis, longlegged myotis, silver-haired bat [Lasionycteris noctivagans], hoary bat [Lasiurus cinereus], eastern red bat [Lasiurus borealis]). Details of capture conditions and locations would be needed to properly determine any bias toward capture of northern myotis in environmental assessments of northern Alberta.

As a result of inconsistent use of genetic testing, patchy sampling of bats, variation in mistnetting techniques, and small sample sizes in most areas, it is not yet clear what the ratio of captures of this species is in relation to other northern Alberta bat species, but Table 1 provides a summary of projects in Alberta reporting capture of at least one northern myotis (captures from most areas and projects not confirmed by genetics). This is an overestimate of relative abundance given that it does not include capture efforts when no northern myotis were captured (i.e., if no northern myotis were captured, data were not reported). Capture ratios from some surveys outside Alberta where northern myotis were captured have been included to allow a crude comparison.

3. Population Trends. - We have no baseline data for bat population sizes in this province and thus no understanding of population trend as anthropogenic disturbance increases in northern Alberta. Sporadic sampling efforts in various locations of northern Alberta have taken place over the past 20 or more years (Table 1); some surveys have been of general bat biodiversity, others targeted certain species for research or environmental assessment. Despite potential inherent biases (see above), these are our only data upon which to infer relative abundance and distribution of northern myotis across central and northern Alberta. 
Table 1. Summary by region of published studies reporting capture of the northern myotis (MYSE) in Canada. Identification of captures from most areas and projects were based on morphometrics only, and were not confirmed by genetic testing.

\begin{tabular}{|c|c|c|c|c|c|}
\hline $\begin{array}{l}\text { General } \\
\text { Location }\end{array}$ & Specific Locations Sampled & $\begin{array}{c}\text { MYSE } \\
\text { captures }\end{array}$ & $\begin{array}{c}\text { Total } \\
\text { bats } \\
\text { captured } \\
\end{array}$ & $\begin{array}{c}\text { Total } \\
\text { species } \\
\text { captured } \\
\end{array}$ & Sources \\
\hline $\begin{array}{l}\text { North-central } \\
\text { Alberta }\end{array}$ & $\begin{array}{l}\text { Caribou River, Wabasca River, } \\
\text { Lesser Slave Lake }\end{array}$ & $\begin{array}{c}2 \\
(4 \%)\end{array}$ & 49 & 4 & $\begin{array}{l}\text { Vonhof and Hobson } \\
\text { (2001) }\end{array}$ \\
\hline $\begin{array}{l}\text { Northwest } \\
\text { Alberta }\end{array}$ & $\begin{array}{l}\text { Rainbow Lake, Sousa Creek, } \\
\text { Grande Prairie, EMEND } \\
\text { Research Area northwest of } \\
\text { Peace River }\end{array}$ & $\begin{array}{c}29 \\
(33 \%)\end{array}$ & 89 & 3 & $\begin{array}{l}\text { Lippert (2001); } \\
\text { Marinelli (2000); } \\
\text { Patriquin (2001); } \\
\text { Vonhof and Hobson } \\
\text { (2001) }\end{array}$ \\
\hline $\begin{array}{l}\text { Northeast } \\
\text { Alberta }\end{array}$ & $\begin{array}{l}\text { Athabasca; Crow Lake; Anzac; } \\
\text { Conklin; Fort MacKay; La } \\
\text { Butte Wildland Provincial Park; } \\
\text { Fidler-Greywillow Wildland } \\
\text { Park; Lac La Biche; various } \\
\text { other locations in the oil sands } \\
\text { area near Fort McMurray }\end{array}$ & $\begin{array}{c}264 \\
(38 \%)\end{array}$ & 697 & 5 & $\begin{array}{l}\text { Crampton (1995); } \\
\text { Grindal et al. } \\
\left.\text { (submitted }^{1}\right) ; \text { Hubbs } \\
\text { and Schowalter (2003) }\end{array}$ \\
\hline Central Alberta & $\begin{array}{l}\text { Whitecourt, Elk Island National } \\
\text { Park, Cooking Lake - Blackfoot } \\
\text { Recreation Area, Edmonton } \\
\text { area, Drayton Valley, Content } \\
\text { Bridge (on Red Deer River), } \\
\text { Battle River (near Donalda and } \\
\text { in Big Knife Prov. Park) }\end{array}$ & $\begin{array}{c}11 \\
(5.5 \%)\end{array}$ & 199 & 6 & $\begin{array}{l}\text { Holroyd (1983); } \\
\text { Lausen }\left(2006 \mathrm{a}^{1}\right) ; \\
\text { Lippert (2001); } \\
\text { Marinelli (2000); } \\
\text { Vonhof and Hobson } \\
(2001)\end{array}$ \\
\hline $\begin{array}{l}\text { OUTSIDE OF } \\
\text { SW Northwest } \\
\text { Territories }\end{array}$ & Nahanni National Park & $3(17 \%)$ & 18 & 4 & Lausen $\left(2006 b^{1}\right)$ \\
\hline Northeast B.C. & $\begin{array}{l}\text { Fort Nelson and Highway } 77 \\
\text { region }\end{array}$ & $9(23 \%)$ & 39 & 4 & Vonhof et al. (1997) \\
\hline $\begin{array}{l}\text { Southeastern } \\
\text { B.C. }\end{array}$ & Revelstoke area & $\begin{array}{c}17 \\
(15.5 \%)\end{array}$ & 110 & 7 & $\begin{array}{l}\text { Haney et al. (2002); } \\
\text { Caceres (1998) }\end{array}$ \\
\hline $\begin{array}{l}\text { New } \\
\text { Brunswick }\end{array}$ & $\begin{array}{l}\text { in and around Fundy National } \\
\text { Park }\end{array}$ & $\begin{array}{c}135 \\
(49 \%)\end{array}$ & 277 & 2 & Broders et al. (2006) \\
\hline
\end{tabular}

${ }^{1}$ some or all Myotis samples were genetically tested for confirmation of species identification; all northern myotis were genetically confirmed. 
Within some areas of its Alberta range, the northern myotis is captured in low ratios (Table 1). For example, 1 of 99 bats captured in the Lac La Biche area (Crampton 1995), 1 of 18 bats captured at Elk Island National Park (Holroyd 1983), 8 of 43 bats captured in the greater Edmonton area (including Elk Island National Park; Vonhof and Hobson 2001), 1 of 83 bats captured in the Red Deer and Battle Rivers Parkland zone (Lausen 2006a), and 4 of 443 bats captured in various central Alberta locations (M. Pybus, unpubl. data; not shown in Table 1) were identified as northern myotis. Substantial capture numbers of northern myotis (264 northern myotis out of a total of 697 captures) have come only from northeastern Alberta as part of numerous environmental impact assessments in the oil sands area around Fort McMurray. If species identifications are reliable (Grindal et al. [submitted] report 14\% - $17 \%$ error in species identifications made by experienced field biologists), then northern myotis appear to be locally abundant in the oil sands area of northeastern Alberta (Grindal et al. submitted), at least in the sites targeted for sampling (before development) in this area. Interestingly, 2008 mistnetting surveys in variouslocationsaroundFt.McMurray produced a northern myotis capture ratio of $6.2 \%$ ( 5 of 81 bat captures were northern myotis; D. Player, unpubl. data). This is in stark contrast to the $38 \%$ northern myotis ratio reported in this area from 1995 - 2006 (Table 1), and may reflect local differences in habitat sampled, weather, or differences in mistnetting techniques, given that most bat captures in the 2008 surveys were in a relatively new commercially available tall netting system using $7.4 \mathrm{~m}$ poles ("triple high net"; Bat Conservation and Management, Pennsylvania) set in fairly wide open cutlines (C. Lausen, pers. obs., D. Player, unpubl. data).

Nearly 30 years ago, northern myotis made up a small proportion of the individuals found hibernating in both Cadomin Cave (Schowalter 1980) and in Wood Buffalo National Park
(Schowalter 1979). Recent surveys of these hibernacula have been point counts without species identifications; therefore, nothing is known of recent relative abundance at these hibernacula.

We cannot definitively say what impact continued industrial development in northeastern Alberta may have on northern myotis populations; however, given their dependence on forest interiors, any development that reduces the present and future density of older stage ("over-mature") trees is likely to reduce the population size of this species.

\section{LIMITING FACTORS}

\section{Availability of Summer Roosting Habitat. -}

There are an increasing number of studies on roosting that find northern myotis roosting in fragmented forested environments. Although these studies provide evidence that northern myotis roost in fragmented forests, we do not have any long-term data to indicate if populations are or are not viable over the long term in these disturbed ecosystems. Recent studies in fragmented forest environments found that northern myotis decrease movement and thereby shrink home ranges size in response to removal of intact forest habitat (Foster and Kurta 1999, Henderson and Broders 2008), which likely reflects limitation of roost and foraging resources, and may ultimately result in decreased population density. In highly fragmented areas of Prince Edward Island, mean movement distance between capture and first-located roosts of northern myotis was $285 \mathrm{~m}$ (Henderson and Broders 2008), which is much smaller than the $1001 \mathrm{~m}$ average movement distance reported in intact forests of New Brunswick (Broders et al. 2006). Foraging areas in intact forests have been reported to be between 46 ha and 65 ha (Broders et al. 2006, Owen et al. 2003), in stark contrast to 6 ha in fragmented areas (Henderson and Broders 2008). Because these bats do not fly in open areas (Henderson and 
Broders 2008, Patriquin and Barclay 2003), it is not surprising to find that home ranges shrink as intact forest fragment size decreases. This corresponding lower availability of resources for roosting and foraging is likely to result in patches accommodating fewer bats (because of emigration or lower reproductive rates; Ricklefs 1990).

Unfortunately, there have been no population size estimates, and no studies of survival and fecundity of northern myotis to demonstrate the impact of industrial activities on this species in highly fragmented ecosystems. As a forestdependent species, northern myotis will have an optimal intact forest patch size, and anything smaller will inevitably compromise roosting and foraging opportunities, thereby decreasing individual fecundity and ultimately population size. It is likely that this minimum intact forest patch size varies across the species' range with local differences in insect, water and roost resources. On Prince Edward Island, Henderson et al. (2008) found the smallest forest fragments used by northern myotis were 17.1 ha and 15.9 ha for females and males, respectively. Studies of northern myotis in areas where intact forest still exists adjacent to fragmented forest find northern myotis preferentially use intact forest (Carter and Feldhamer 2005, Owen et al. 2003).

There are mixed results in the literature regarding type of tree roosts selected by northern myotis. Some roosting studies of this species conclude that they depend on mature/old growth forests (as summarized in Caceres and Pybus 1997), with bats selecting large diameter tall roost trees (Sasse and Pekins 1996, Vonhof and Wilkinson 1999); other studies conclude that the northern myotis is more of a treeroosting generalist, roosting in trees of various height, diameter, and decay stages (e.g., Carter and Feldhamer 2005, Foster and Kurta 1999, Vonhof et al. 1997). Additionally, it is not clear whether stand age is important for roost plots; in a study in South Dakota, a few northern myotis were documented roosting in remnant snags in recently forested plots ( $<5$ years; Cryan et al. 2001), although the largest maternity colony of northern myotis in this study $(n=41)$ was found in a nearby mature forest stand that had not been harvested in more than 50 years (Cryan et al. 2001). Many studies implicate the importance of snag density and stem density in roost plots, suggesting relatively abundant snags and dense forest are habitat requirements for this species (Cryan et al. 2001, Foster and Kurta 1999, Menzel et al. 2002, Owen et al. 2002, 2003).

A common thread among roost studies for northern myotis seems to be the preference for deciduous trees, especially for females (e.g., Broders and Forbes 2004, Henderson and Broders 2008, Henderson et al. 2008). Studies of northern myotis in agricultureforest mosaic landscapes (eastern Canada and Michigan) found that females of this species roost exclusively in deciduous trees (Foster and Kurta 1999, Henderson and Broders 2008). However, the importance of coniferous trees in some locations has also been reported (e.g., Lacki and Schwierjohann 2001), especially for males (Broders and Forbes 2004, Henderson et al. 2008). This suggests that mixedwood stands are important for northern myotis because of intersexual variation in habitat selection. In the past, forest policy in Alberta generally favoured exploitation and subsequent elimination of mixedwood stands, with reforestation to pure deciduous or pure conifer stands typical (Province of Alberta 1991). Modeling of northern Alberta forest structure based on a variety of these harvesting practices predicted between $0 \%$ and $10 \%$ old-growth deciduous and between $0 \%$ and $23 \%$ old-growth coniferous remaining in 300 years, with the conclusion that projected levels of tree harvesting would be sustainable, but many wildlife species would lose large amounts of preferred habitat (Cumming et al. 1994). Some current Forest Management Plans suggest a move toward trying to maintain more mixedwood stands and 
retention of a greater percentage of old-growth trees (e.g., Alberta-Pacific 2006).

On Prince Edward Island, Henderson and Broders (2008) suggested that radio-tracked northern myotis foraged along forested riparian areas rather than in the surrounding cleared areas, not because of prey availability, but because of a strong preference for foraging and commuting within forested landscapes. The presence of this species in highly fragmented landscapes suggests northern myotis could be more resilient to some degree of forest fragmentation than once believed; however, there is a need to conduct roosting and foraging studies of this species in Alberta.

Presumably, this species has evolved with a natural disturbance regime, with fire creating a mosaic of live and dead trees in clumped patches (Hansson 1992, EMEND 2006). Bats may be able to shift their behaviour in response to small habitat disturbances (Patriquin and Barclay 2003); however, in large scale disturbances such as large clearcuts or fires with salvage logging, few over-mature (older than typically required for harvesting), dying or dead trees remain (Hansson 1992) to be used as bat roosts. Furthermore, changes in the density of vegetation will influence insect abundance and foraging opportunities, especially for gleaning bat species, such as northern myotis, who prefer and seemingly depend on vegetatively cluttered habitat. Patriquin and Barclay (2003) found in Alberta that clear-cutting of forests resulted in increased activity of larger species of bats that typically forage away from clutter (i.e., silver-haired bat), but decreased activity of northern myotis. This likely reflects their gleaning behaviour and tendency to stay within intact forest. Forestry activities should strive to mimic a natural disturbance regime, leaving a mosaic of interconnected forest patches varying in tree density (Walker et al. 1995, Patriquin and Barclay 2003). Unfortunately, the largescale hot-burning fires that more typically occur today where fires have been historically suppressed tend to clear large tracts of forest rather than leave a patch mosaic of living and dead trees (Agee 1996). An example of a severe forest fire in northern Alberta is the House Fire of 2002, which burned 250,000 ha of forest in northeastern Alberta; salvage logging occurred over much of this area (Macdonald 2006).

The Alberta boreal forest covers a vast area, but how much of this forest is usable roosting habitat for northern myotis is not known. Just as the forest harvesting industry recognizes that not all of the boreal forest contains trees usable for timber (e.g., only one third of AlPac Forest Products, Inc. Forest Management Area contains trees usable for timber; AlbertaPacific 2006), much of the boreal area may be unsuitable for northern myotis. Once roosting requirements for this species in Alberta are understood, we will know what percentage of the boreal forest is currently suitable habitat for this species.

2. Hibernacula - The availability of suitable hibernacula may be a limiting factor in northern myotis populations. Natural caves or abandoned mines may be in short supply over much of the species' range in northern Alberta. In addition, environmental limitations that govern successful hibernation make many mines and caves unsuitable (Ministere de l'Environment et de la Faune 1996).

Hibernating bats are particularly sensitive to disturbance (Thomas 1995). They have limited stored energy supplies and have no opportunity to replace energy expended during the winter. To conserve energy, northern myotis, like many bat species, are true hibernators. That is, they enter a state of torpor in which their internal body temperature approaches freezing, and their breathing and heart rate are significantly slowed. Bats will arouse from torpor to seek water, or move to another location if environmental conditions become unsuitable (for example, if the hibernaculum becomes too warm or cold), or if they are physically disturbed. Most often this 
latter disturbance is related to human activity within the hibernaculum (Thomas 1995).

In general, bat hibernation is poorly understood. Bats arouse periodically throughout the winter for various reasons, and may fly, although why flight occurs is not yet understood given its energetic expense to a hibernating bat (Lausen and Barclay 2006a). Each time a bat arouses from torpor, it uses significant energy supplies to warm its body and increase its metabolic rate. Arousals generally account for $80 \%$ to $90 \%$ of the energy expenditure in hibernating animals during the winter (Thomas et al. 1990). Thus, if bats repeatedly arouse during the winter, they may expend all their energy supplies and die. Human disturbances in hibernacula have the potential to cause some bats to arouse more frequently than can be supported by their fat reserves.

Hibernating bats are more sensitive to human presence than was previously supposed. Thomas (1995) documented arousal and flight of hibernating bats within 30 minutes of humans entering a hibernaculum of little brown myotis and northern myotis. The disturbing stimulus appeared to be the mere presence of humans and their associated lights and sounds. At no time did any of the humans touch or closely approach the hibernating bats. Further, increased bat activity continued for up to seven or eight hours after the humans had left the cave. This implies that aroused bats may have been disturbing torpid bats, resulting in other bats arousing. Thus, the original disturbance by humans is magnified among the hibernating bats. In some cases it may be desirable to prevent unnecessary disturbance by blocking the entrance to a hibernaculum. Barred gates may be used to allow entry only by bats and authorized humans or to limit access to times when bats are not at risk (for example, summer). However, there are some inherent risks with this approach, such as the potential destruction of the gate and surrounding cave entrance by humans wishing to regain access to the cave/ mine (C. Lausen, pers. obs.), and the potential alteration of airflow, cave microclimate, and the cave ecosystem; furthermore, gates may make access to the cave by various wildlife, including bats, more difficult (Elliot 2006, Martin et al. 2000). Gating should be properly assessed to determine its necessity, appropriate structure, and placement; all aspects of access management need to be carefully evaluated before using gates as a tool (Elliot 2006).

The abundance of the northern myotis may be limited by closing or otherwise altering old mines or caves that are essential for hibernation. Changes to the internal environment of a hibernaculum may also result in its abandonment by bats. Although there are no records of closures of known bat hibernacula in Alberta, such situations have occurred elsewhere (Taylor 1995, 1996, Tuttle 1996). Furthermore, our lack of knowledge regarding the hibernation sites of the northern myotis in Alberta could lead to unintentional disturbance or destruction of hibernacula. Because it has recently been shown that some species of bats in Alberta hibernate in deep rock crevices along river valley walls (Lausen and Barclay 2006a), and not necessarily in caves, it is possible that a large number of bat hibernation sites have been overlooked and could easily be destroyed or disturbed.

In addition to providing critical winter habitat, hibernacula are also important as sites of swarming (breeding behaviour) in many bat species. Many bats that swarm at a site do not hibernate there (Fenton 1983). This is a critical period and the only time when large numbers of male and female bats occur in the same place at the same time. In Alberta, swarming of Myotis spp. at Cadomin Cave occurs in late August and early September (Schowalter 1980). Although a few northern myotis were caught there, it is not known if Cadomin Cave is a primary swarming site for this species. Protection of swarming sites is particularly important for breeding purposes, and has 
implications beyond the group of bats that use the specific hibernaculum. Alteration of the site or disturbance of the bats during swarming should be kept to a minimum.

3. White Nose Syndrome. - When the number of hibernacula is low, bat populations are disproportionately clumped at a time when they are most vulnerable. This increases the risk that a catastrophic event may seriously reduce the population. Such a catastrophic event has taken place recently in cave hibernacula in the northeastern United States. White Nose Syndrome (WNS) is a recent phenomenon describing the occurrence of a white fungus on hundreds of thousands of dead bats during hibernation in 2006-2007 and 2007-2008. This fungus thrives at cold temperatures, propagating in bat tissue when bats are in torpor with suppressed immune function (Blehert et al. 2008). Fungal hyphae fill hair follicles, sebaceous glands and sweat glands, eroding the epidermis of ears and wings, which likely stimulates an arousal by bats to boost immune function; most bats found dead with this fungus had little or no identifiable fat reserves, suggesting starvation (Blehert et al. 2008).

Currently, WNS is found only in the northeastern United States, and its long distance spread from one to five states in one winter season (2007 - 2008) led the US Fish and Wildlife Service to issue containment and decontamination protocols for bat biologists and cavers visiting caves in the affected and neighbouring states (U.S. Fish and Wildlife Service 2008). Winter survey counts of all bat species in affected cave hibernacula show declines ranging from $81 \%$ to $97 \%$ (Hicks et al. 2008). WNS in bats has been likened to chytridiomycosis, a lethal fungal skin infection associated with recent worldwide declines of amphibians (as summarized in Blehert et al. 2008). It is suspected that bats transfer the fungal spores of this syndrome to neighbouring locations; however, it is likely that humans (e.g., cavers, bat biologists) can propagate the spread of this fungus unless precautions are taken (U.S. Fish and Wildlife Service 2008). It is forecast that WNS may spread into southern Canada during the winter of 2008 - 2009 (CBC 2008). Although little is known about bat hibernacula in Alberta, it is possible that appropriate microclimatic conditions could exist for this fungus to affect Alberta bats, should the spores reach this province. It is speculated that spores can lie dormant, but remain viable, in inappropriate (i.e., warm, dry) conditions, allowing the spread of the fungus through inhospitable habitats or seasons (D. Blehert, pers. comm.).

It has recently been predicted that if WNS continues at its current rate of spread and fatality, that little brown myotis, northern myotis and tri-coloured bat (Eastern pipistrelle; Perimyotis subflavus) will be extirpated from eastern North America (Hicks et al. 2008). Only time will tell whether WNS represents a threat to cave-hibernating species in western North America, and whether the western populations of northern myotis will have elevated importance on a continental scale as eastern populations continue to decline. Because so few Myotis hibernacula are known in Alberta, and bat population numbers are unknown, it is possible that if WNS were to affect bats in this province, its presence would go unnoticed for quite some time, evident only when highly scarred wing tissues are noticed or if drastic declines in summer populations of cave-hibernating species are documented.

4. Climate Change. - In general, bat distributions and abundance in Canada tend to be limited by climate and availability of suitable roost sites (van Zyll de Jong 1985). Overlying this trend is a pattern of decreased diversity and abundance of bats with increasing latitude north of the equator. As such, in the northern temperate regions of Canada, the number of bat species and individuals is relatively low. The most northerly distribution tends to coincide with the limit of mean annual growing season of 120 days; that is, the period during which 
the mean daily temperature remains above $6^{\circ} \mathrm{C}$ (van Zyll de Jong 1985). This appears to reflect the minimum time needed for female bats to produce young and have them successfully grow and develop to the stage where they can survive hibernation. Thus, climate may be the ultimate limiting factor on the northern distribution of northern myotis. Their distribution may shift north with climate change (Humphries et al. 2002), although other factors, such as availability of roosts and length of nights are likely to limit northern expansion.

Recently it has been determined that climate change has increased the mortality rate of trees across the western United States, with mortality rates doubling over a 17 -year period in Pacific Northwest forests, and over a 29-year period in Interior forests (van Mantgem et al. 2009). Slightly warmer and drier conditions have been implicated as the cause of this increased mortality, reduced recruitment, and changed forest structure and composition discovered in long term datasets of unmanaged old growth forests. All sizes and species of trees are experiencing increased mortality across the west. Van Mantgem et al. (2009) point out that a persistent doubling of tree mortality rate in oldgrowth forests would ultimately cause a greater than $50 \%$ reduction in average tree age in these undisturbed forests and hence a potential overall reduction in mean tree size. As these findings are new, it is not yet clear what impact this will have on northern myotis and other tree-dwelling bat species in the long term, but if density and size of trees in old-growth stands continue to decrease, roosting and foraging habitats will inevitably be altered.

\section{STATUS DESIGNATIONS*}

1. Alberta. - In 1991, the general status of the northern myotis was considered Undetermined

\footnotetext{
* See Appendix 1 for definitions of selected status designations.
}

because of the lack of information on the biology and population trends of this species (Alberta Fish and Wildlife Division 1991). However, in 1996, the species was moved to the "Blue List" of species that may be at risk in the province (Alberta Environmental Protection 1996). This change in status was based on the relative rarity of the species in the province, and on its apparent reliance on mature trees for roosting. Since 2000, this general status category has been renamed as May Be At Risk in Alberta (Alberta Sustainable Resource Development 2001, 2007).

Although the provincial general status of May Be At Risk offers no legal protection for those wildlife species, hibernacula of the northern myotis, and all other bats in Alberta, are afforded protection from disturbance between September 1 and April 30 under Section 38 (1) of Alberta's Wildlife Act.

As a group, bats are identified in the Wildlife Act (1986) as "non-licence" species. This designation means that bats can be hunted or harvested without a permit. However, it is not legal to possess live bats in Alberta (Section 3, Captive Wildlife Regulation of Alberta's Wildlife Act) because of the concern for public safety. A permit is required to handle bats for research purposes (Wildlife Regulation 143/97, SS. 81, 82).

The Alberta Natural Heritage Information Centre ranks the northern myotis as S2S3 (tracking hibernacula only) because of concern for roosting and breeding habitat (Alberta Natural Heritage Information Centre 2007, 2008).

2. Other Areas. - Given its broad range and relatively abundant populations in the east, northern myotis has a Canadian general status rank of Secure, which changed from its rank of Sensitive in 2000 (CESCC 2006). Quebec is currently the only state/province in the North American distribution of this species that lists 
northern myotis as Secure (NatureServe 2008). If WNS spreads to eastern Canada from eastern U.S., as predicted, this Secure designation will most likely change.

The northern myotis is on the "Blue List" (special concern - at risk but not threatened) in British Columbia (B.C. Conservation Data Centre 2008). This species was recently discovered in the Yukon (Jung et al. 2006; Lausen et al. 2008), where it was given a May Be At Risk general status rank (T. Jung, pers. comm.). Northern myotis was known from only a few specimens in the Northwest Territories prior to 2006 when this species made up 17\% of the captures in a formal survey of Nahanni National Park Reserve in the southwestern part of the territory (Lausen 2006b). It currently has not been ranked in the Northwest Territories (Status Undetermined; Working Group on General Status of NWT Species 2006). In the Maritimes, where the most research has occurred on this species in Canada, northern myotis is ranked as Sensitive (CESCC 2006). In forested areas, this species is captured nearly as often as the little brown myotis in New Brunswick (see Table 1; Broders et al. 2006), and in greater numbers than the little brown myotis in Nova Scotia (Broders et al. 2003); its ranking as Sensitive in these areas stems from its dependency on forests, a heavily exploited resource in many areas of Canada.

NatureServe classifies this species as S2S3 (imperilled/vulnerable) in B.C., Yukon and Montana (NatureServe 2008). In Saskatchewan, the breeding population is considered S4 (apparently secure), while the nonbreeding populations remain unranked (SNRN; NatureServe 2008). In Manitoba, the breeding population is also considered S4 and the nonbreeding population is considered S3S4. Globally, NatureServe ranks the northern myotis as G4 (apparently secure, last reviewed 19 April 2005; NatureServe 2008).

\section{RECENT MANAGEMENT IN ALBERTA}

Other than baseline efforts to document detailed status (Caceres and Pybus 1997), no management or research activities specifically focused on northern myotis have taken place in Alberta.

\section{SYNTHESIS}

An accurate assessment of the status of a species requires an understanding of its basic biology, ecology, and population size and trends over time. For the northern myotis, we have some basic information concerning its life history and habitat preferences, and can make limited inferences from knowledge of closely related species to fill in some information gaps. However, there are no good baseline data upon which to estimate population size or deduce/predict trends. Confusion over species identification has been a complicating factor in understanding the distribution and relative abundance of this species. While this species was likely underestimated in early bat studies of northern Alberta, it is now equally possible that it is overestimated if ear length and pelage colour are the only criteria used to differentiate this species from other similar Myotis. Acoustically, northern myotis is difficult to differentiate from other Myotis because of overlap of call characteristics, and any attempt to do so is likely to either underestimate or overestimate its abundance, depending on criteria used. DNA sampling of captures with subsequent genetic sequencing is the only way to ensure correct species identification. Special effort needs to be made to set mistnets that are most suitable for catching this species (i.e., nets that are set in vegetatively cluttered areas and extend to the ground and to vegetative edges). To best estimate species ratios, variation in netsets needs to be used to maximize the likelihood of catching all possible species (i.e., tall nets in addition to nets that extend to the ground; nets in vegetatively cluttered areas and in open 
areas; nets over water; nets on narrow and wide trails/cutlines and in intact forest).

Capture records suggest northern myotis occur at varying densities across a broad area of northern Alberta. This species requires intact forest stands for roosting and foraging during the summer; however, patch sizes, and preferred roost tree and stand characteristics are not known for Alberta. Caves appear to be the preferred hibernacula, but other sources of hibernacula such as rocky riparian areas have not been investigated. Only two caves in Alberta are known to contain hibernating northern myotis.

Recent roosting and foraging studies from outside of Alberta and Canada have shed light on the ecology of this species, but have also produced some conflicting findings. Even though northern myotis are increasingly being found in young forests, population viability studies have yet to be conducted. Finding northern myotis in these habitats, which were not previously associated with this species but are increasingly available, may be indicative of plasticity in behaviour or merely philopatry (returning to place of birth). Longterm persistence of this species in disturbed ecosystems has yet to be documented. Local studies, specific to Alberta, are likely to be more informative than extrapolation of results from other ecosystems. More extensive and intensive mistnetting surveys are needed in Alberta; only the oil sands area near Fort McMurray has been extensively surveyed, with relatively large numbers of northern myotis being reported from this northeastern Alberta location. Most of these northeastern Alberta surveys have been done as part of environmental assessments prior to industrial developments. It is not clear whether post-development surveys would yield similar capture rates of the species; similarly, because of a lack of bat research in Alberta's Boreal Forest Natural Region, habitat requirements of northern myotis and response to forest fragmentation are unknown, making it unclear what the long-term population trend might be for northern myotis in these increasingly developed industrial regions.

The Alberta boreal forest covers a vast area, and the natural patchiness of suitable intact forest habitat suggests northern myotis are likely to be patchily distributed. It is difficult to accurately assess the proportion of Alberta's boreal forest that can be considered suitable habitat for this species, or the impacts that may result from various resource extraction activities (such as forestry), knowing so little about the habitat requirements for this species in Alberta. Because summer roosting requirements have been shown to differ between males and females, and the distribution of males and females seems to be affected by fragmentation at different scales (forest fragment scale for females, landscape scale for males), roosting studies of both sexes are required so that strategies for viable northern myotis populations are written into forest management plans.

Roost selection criteria for both males and females of this species in Alberta (at three scales: tree, stand, and landscape) should be considered a priority research item. A habitatbased model for Alberta should follow, in order to determine the degree of threat of industrial activities to the northern myotis bat in Alberta. Habitat suitability models in New Brunswick have shown a preference for deciduous-dominated stands by females, and a preference for coniferous-dominated stands by males. In Alberta, because we do not know roost preferences, we cannot predict what impact industrial activities will have on male and female northern myotis, the degree of fragmentation northern myotis may tolerate in the boreal ecosystem, and what minimum and optimal patch sizes of intact forest (deciduous, coniferous, mixedwood) are required to maintain a viable population. In addition, more hibernation and breeding sites need to be located, not only to avoid accidental destruction of such critical habitat resources, 
but also to ensure that forest patch dynamics facilitate necessary movement patterns by individuals. Given that this species is thought to remain only in forest interiors, commuting within the forest or along forest edges, but not through open environments (Hogberg et al. 2002), it would be critical to accommodate nightly movements for drinking, foraging, and roosting, and seasonal movements for mating and hibernating. Only with these data could appropriate forest management plans be designed to ensure the persistence of healthy populations of this forest-dependent species in Alberta.

Minimal survey effort has gone into surveying bats in northwestern Alberta; more inventory work should be done here, as well as in northcentral and central Alberta, to understand whether the northern myotis is common across its range in Alberta, or patchily distributed. All bat surveys should include intensive research programs, including radiotelemetry studies, which would allow identification of male and female roost sites and a quantitative assessment of the year-round habitat requirements and preferences of this species. Such information would not only enhance our ability to assign an appropriate status ranking for this species, but it would provide data for design of appropriate forest management plans, and clarify potential factors that might limit the abundance and distribution of the northern myotis in the province. 


\section{LITERATURE CITED}

Agee, J.K. 1996. Fire Ecology of Pacific Northwest Forests. Island Press, Washington, D.C. 505 pp.

Alberta Environmental Protection. 1996. The status of Alberta wildlife. Alberta Environmental Protection, Natural Resources Service, Wildlife Management Division. Edmonton, AB. 44 pp.

Alberta Fish and Wildlife Division. 1991. The status of Alberta wildlife. Alberta Forestry, Lands and Wildlife. Edmonton, AB. 49 pp.

Alberta-Pacific. 2006. Alberta-Pacific Forest Products, Inc. Forest Management Plan. Approved January 16, 2006. Prepared for Alberta Sustainable Resource Development as required by the Al-Pac Forest Management Agreement March 17, 1999. URL: http://srd.alberta.ca/forests/managing/ plans/albertapacific.aspx [Accessed: 28 Dec. 2008].

Alberta Natural Heritage Information Centre (ANHIC). 2006. Natural Regions and Subregions of Alberta. URL: http://tpr. alberta.ca/parks/heritageinfocentre/ naturalregions/default.aspx [Updated 15 December 2006].

Alberta Natural Heritage Information Centre (ANHIC). 2007. Explanation of Ranks. Alberta Tourism, Parks and Recreation. URL: http://tpr.alberta. $\mathrm{ca} /$ parks/heritageinfocentre/animals/ definitions.aspx [Updated: 1 October 2007].

Alberta Natural Heritage Information Centre (ANHIC). 2008. Mammal tracking list. Alberta Tourism, Parks and
Recreation. URL: http://tpr.alberta. ca/parks/heritageinfocentre/animals/ mammalstrack.aspx [Updated: 1 February 2008].

Alberta Sustainable Resource Development. 2001. The general status of Alberta wild species 2000. Alberta Sustainable Resource Development, Fish and Wildlife Service. Edmonton, AB. 46 pp.

Alberta Sustainable Resource Development. 2007. The general status of Alberta wild species 2005. URL: http://srd. alberta.ca/fishwildlife/speciesatrisk/ statusofalbertawildspecies/ [Accessed: 18 May 2008].

Altringham, J.D. 1996. Bats: Biology and behaviour. Oxford University Press, Oxford.

B.C. Conservation Data Centre. 2008. BC Species and Ecosystems Explorer. B.C. Ministry of Environment, Victoria, BC. URL: http://a100.gov.bc.ca/pub/ eswp/ [Accessed: 20 May 2008].

B.C. Ministry of Environment. 2008. Ecosystems Branch. B.C. Species and Ecosystems Explorer. Myotis septentrionalis. URL: http://env.gov. bc.ca/atrisk/toolintro.html [Accessed: 5 May 2008].

Barbour, R.W., and W.H. Davis. 1969. Bats of America. The University Press of Kentucky, Lexington, KY. 286 pp.

Barclay, R.M.R. 1991. Population structure of temperate zone insectivorous bats in relation to foraging behaviour and energy demand. Journal of Animal Ecology 60: 165-178.

Barclay, R.M.R., J. Ulmer, C.J.A. MacKenzie, M.S. Thompson, L. Olson, J. McCool, 
E. Cropley, and G. Poll. 2004. Variation in the reproductive rate of bats. Canadian Journal of Zoolgy 82: 688-693.

Blehert, D.S., A.C. Hicks, M. Behr, C.U. Meteyer, B.M. Berlowski-Zier, E.L. Buckles, J.T.H. Coleman, S.R. Darling, A. Gargas, R. Niver, J.C. Okoniewski, R.J. Rudd, W.B. Stone. 2008. Bat white-nose syndrome: an emerging fungal pathogen? Published online 30 October 2008 [DOI: 10.1126/ science.1163874] Science Express Brevia.

Brandon, R.A. 1961. Observations of young Keen Bats. Journal of Mammalogy 42: 400-401.

Broders, H.G., C.S. Findlay, L. Zheng. 2004. Effects of clutter on echolocation call structure of Myotis septentrionalis and M. lucifugus. Journal of Mammalogy 85: 273-281.

Broders, H.G., and G.J. Forbes. 2004. Interspecific and intersexual variation in roost-site selection of northern longeared and little brown bats in the Greater Fundy National Park Ecosystem. Journal of Wildlife Management 68: 602-610.

Broders, H.G., G.J. Forbes, S. Woodley and I.D. Thompson. 2006. Range extent and stand selection for roosting and foraging in forest-dwelling northern long-eared bats and little brown bats in the Greater Fundy Ecosystem, New Brunswick. Journal of Wildlife Management 70: 1174-1184.

Broders, H.G., G.M. Quinn, and G.J. Forbes. 2003. Species status, and the spatial and temporal patterns of activity of bats in southwest Nova Scotia, Canada. Northeastern Naturalist 10: 383-398.
Caceres, M.C. 1998. The summer ecology of Myotis species bats in the interior wet-belt of British Columbia. MSc thesis. University of Calgary, Calgary, Alberta.

Caceres, M.C., and R.M.R. Barclay. 2000. Myotis septentrionalis. Mammalian Species No. 634: 1-4.

Caceres, M.C., and M.J. Pybus. 1997. Status of the Northern Long-eared Bat (Myotis septentrionalis) in Alberta. Alberta Environmental Protection, Wildlife Management Division, Wildlife Status Report No. 3, Edmonton, AB. 19 pp.

Caire, W., R.K. LaVal, M.L. LaVal, and R. Clawson. 1979. Notes on the ecology of Myotis keenii (Chiroptera, Vespertilionidae) in Eastern Missouri. American Midland Naturalist 102: 404-407.

Canadian Endangered Species Conservation Council (CESCC). 2006. Wild Species 2005: The General Status of Species in Canada. 141 pp. URL: http://www. wildspecies.ca. [Accessed: 11 Nov. 2006].

Carter, T.C., and G.A. Feldhamer. 2005. Roost tree use by maternity colonies of Indiana bats and northern longeared bats in southern Illinois. Forest Ecology and Management 219: 259268.

CBC. 2008. Canada well within reach of bats carrying white-nose syndrome. Canadian Broadcasting Corporation. Online news May 14, 2008. URL: http://www.cbc.ca/ canada/montreal/story/2008/05/14/ qc-batscanadaquebec $0514 . h \mathrm{tml}$. [Accessed: 30 Dec. 2008]. 
Chung-MacCoubrey, A.L. 2005. Use of pinyon-juniper woodlands by bats in New Mexico. Forest Ecology and Management 204: 209-220.

Clark, B.S., J.B. Bowles, and B.K. Clark. 1987. Summer occurrence of the Indiana Bat, Keen's Myotis, Evening Bat, Silver-haired Bat and Eastern Pipistrelle in Iowa. Proceedings of the Iowa Academy of Science 94: 89-93.

COSEWIC. 2006. Definitions and Abbreviations. Committee on the Status of Endangered Wildlife in Canada. URL: http://www.cosewic. gc.ca [Updated: April 2006].

Crampton, L. 1995. Habitat selection by bats and the potential impacts of forest fragmentation on bat populations in aspen mixedwood forests in northern Alberta. M.Sc. thesis. University of Calgary, Calgary, AB. 114 pp.

Crampton, L.H., and R.M.R. Barclay. 1998. Selection of roosting and foraging habitat by bats in different-aged aspen mixedwood stands. Conservation Biology 12: 1347-1358.

Cryan, P.M., M.A. Bogan, and G.M. Yanega. 2001. Roosting habits of four bat species in the Black Hills of South Dakota. Acta Chiropterologica 3: 4352.

Cumming, S.G., P.J. Burton, S. Prahacs, and M.R. Garland. 1994. Potential conflicts between timber supply and habitat protection in the boreal mixedwood of Alberta, Canada: a simulation study. Forest Ecology and Management 68: 281-302.

Dewey, T.A. 2006. Systematics and phylogeography of North American
Myotis (Chiroptera: Vespertilionidae). $\mathrm{PhD}$ Dissertation, University of Michigan, Ann Arbor, MI. 164 pp.

Dobbyn, J. 1994. Atlas of the mammals of Ontario. Federation of Ontario Naturalists, Don Mills, ON. 120 pp.

Elliot, W.R. 2006. Cave gating criteria. Resource Science Division, Missouri Dept. of Conservation. $7 \mathrm{pp}$.

EMEND. 2006. Ecosystem management emulating natural disturbance project. Biologically-based research in forest management. www.emend.rr.ualberta. ca. [Accessed: 14 May 2009].

Faure,P.A.,J.H.Fullard, and J.W.Dawson. 1993. The gleaning attacks of the Northern Myotis, Myotis septentrionalis, are relatively inaudible to moths. Journal of Experimental Biology 178: 173189.

Fenton, M.B. 1983. Just Bats. University of Toronto Press. Toronto, ON. 165 pp.

Fenton, M.B. 1990. The foraging behaviour and ecology of animal-eating bats. Canadian Journal of Zoology 68: 411422.

Fenton, M.B., and G.P. Bell. 1979. Echolocation and feeding behaviour in four species of Myotis (Chiroptera). Canadian Journal of Zoology 57: 1271-1277.

Fenton, M.B., H.G. Merriam, and G.L. Holroyd. 1983. Bats of Kootenay, Glacier, and Mount Revelstoke national parks in Canada: identification by echolocation calls, distribution, and biology. Canadian Journal of Zoology 61: 2503-2508. 
Fitch J.H., and K.A. Shump Jr. 1979. Myotis keenii. Mammalian Species 121:1-3.

Ford, W.M., S.F. Owen, J.W. Edwards, and J.L. Rodrigue. 2006. Robinia pseudoacacia (Black locust) as day-roosts of male Myotis septentrionalis (Northern bats) on the Fernow Experimental Forest, West Virginia. Northeastern Naturalist 13: $15-24$.

Foster, R.W., and A. Kurta. 1999. Roosting ecology of the northern bat (Myotis septentrionalis) and comparisons with the endangered Indiana bat (Myotis sodalis). Journal of Mammalogy 80 : 659-672.

Garroway, C.J., and H.G. Broders. 2007. Nonrandom association patterns at northern long-eared bat maternity roosts. Canadian Journal of Zoology 85: 956-964.

Godin, A.J. 1977. Wild mammals of New England. Johns Hopkins University Press, Baltimore, MD. 304 pp.

Griffin, D.R. 1940. Notes on the life histories of New England cave bats. Journal of Mammalogy 21: 181-187.

Grindal, S.D., T.S. Collard, R.M. Brigham, and R.M.R. Barclay. 1992. The influence of precipitation on reproduction by Myotis bats in British Columbia. American Midland Naturalist 128: 339-344.

Grindal, S.D., C. Stefan, and C. GodwinSheppard. Submitted. Bats in the oil sands regions of Alberta. Northwestern Naturalist.

Hall, J.S., R.J. Clouthier, and D.R. Griffin. 1957. Longevity records and notes on tooth wear of bats. Journal of Mammalogy 38: 407-409.
Hamilton, W.J., and J.O. Whitaker. 1979. Mammals of the eastern United States, 2nd ed. Cornell University Press, Ithaca, NY. 346 pp.

Haney, A., M.J. Sarell, and J.B. Runciman. 2002. Revelstoke Community Forest Corporation, TFL 56 Northern Longeared Bat Inventory 2000-2002. Final Report for Revelstoke Community Forest Corporation, Revelstoke, B.C.

Hansson, L. 1992. Landscape ecology of boreal forests. Trends in Ecology and Evolution 7: 299-302.

Henderson, L.E. 2007. The effects of forest fragmentation on the forest-dependent northern long-eared bat (Myotis septentrionalis). MSc thesis, Saint Mary's University. Halifax, Nova Scotia. 114 pp.

Henderson, L.E., and H.G. Broders. 2008. Movements and resource selection of the northern long-eared myotis (Myotis septentrionalis) in a forest-agriculture landscape. Journal of Mammalogy 89: 952-963.

Henderson, L.E., L.J. Farrow, and H.G. Broders. 2008. Intra-specific effects of forest loss on the distribution of the forestdependent northern long-eared bat (Myotis septentrionalis). Biological Conservation 141: 1819-1828.

Hicks, A.C., C.J. Herzog, R. Vonlinden, S.R. Darling, S.L. von Oetting, R.A. Niver, J.T. H. Coleman. 2008. White nose syndrome: the history and current status of an unprecedented threat to hibernating bats in NorthAmerica. 38th Annual NorthAmerican Symposium on Bat Research. Scranton, Pennsylvania, Oct. 22 - 25, 2008. 
Hitchcock, H.B. 1949. Hibernation of bats in southeastern Ontario and adjacent Quebec. Canadian Field-Naturalist 63: 47-59.

Hogberg, L.K., K.J. Patriquin, and R.M.R. Barclay. 2002. Use by bats of patches of residual trees in logged areas of the Boreal Forest. American Midland Naturalist 148: 282-288.

Holroyd, G.L. 1983. A brief survey of the bats of Elk Island National Park. Blue Jay 41: 217-222.

Hubbs, A., and T. Schowalter. 2003. Survey of bats in Northeastern Alberta. Alberta Sustainable Resource Development, Fish and Wildlife Division, Alberta Species at Risk Report No. 68. Edmonton, AB. 18 pp.

Humphrey, S.R., A.R. Richter, and J.B. Cope. 1977. Summer habitat and ecology of the endangered Indiana bat, Myotis sodalis. Journal of Mammalogy 58: 334-346.

Humphries, M.M., D.W. Thomas, and J.R. Speakman. 2002. Climate-mediated energetic constraints on the distribution of hibernating mammals. Nature (London) 418: 313-316.

Jung, T.S, B.G. Slough, D.W. Nagorsen, T.A. Dewey, and T. Powell. 2006. First Records of the Northern Long-Eared Bat, Myotis Septentrionalis, in the Yukon Territory. Canadian FieldNaturalist 120: 39-42.

Jung, T.S., I.D. Thompson, and R.D. Titman. 2004. Roost site selection by forestdwelling male Myotis in central Ontario, Canada. Forest Ecology and Management 202: 325-335.
Jung, T.S., I.D. Thompson, R.D. Titman, and A.P. Applejohn. 1999. Habitat selection by forest bats in relation to mixed-wood stand types and structure in central Ontario. Journal of Wildlife Management 63: 1306-1319.

Kalcounis-Rüppel, M.C., J.M. Psyllakis, and R.M. Brigham. 2005. Tree roost selection by bats: an empirical synthesis using meta-analysis. Wildlife Society Bulletin 33: 1123-1132.

Knox Jones, J.,D. M.Armstrong, R.S.Hoffmann, and C. Jones. 1983. Mammals of the northern Great Plains. University of Nebraska Press, Lincoln, NE. 379 pp.

Kurta, A. 1995. Mammals of the Great Lakes region, revised edn. University of Michigan Press, Ann Arbor, MI. 376 pp.

Lacki, M. J., and J. T. Hutchinson. 1999. Communities of bats (Chiroptera) in the Grayson Lake region, northeastern Kentucky. Journal of the Kentucky Academy of Science 60:9-14.

Lacki, M.J., and J.H. Schwierjohann. 2001. Day-roost characteristics of northern bats in mixed mesophytic forest. Journal of Wildlife Management 65: 482-488.

Lausen, C.L. 2006a. 2005-2006 bat survey of the middle Red Deer and Battle rivers. Unpublished report prepared for Alberta Natural Heritage Information Centre, Parks and Protected Areas Division, 2nd Floor, Oxbridge Place 9820 - 106 St., Edmonton, AB. iv + $22 \mathrm{pp}$.

Lausen, C.L. 2006b. Bat survey of Nahanni National Park Reserve and surrounding areas, Northwest Territories. $45 \mathrm{pp}$. 
Available from: Nahanni National Park Reserve, Fort Simpson, Northwest Territories, Canada.

Lausen, C.L., and R.M.R. Barclay. 2003. Thermoregulation and roost selection by reproductive female big brown bats (Eptesicus fuscus) roosting in rock crevices. Journal of Zoology (London) 260: 235-244.

Lausen, C.L., and R.M.R. Barclay. 2006a. Winter bat activity in the Canadian prairies. Canadian Journal of Zoology 84: 1079-1086.

Lausen, C.L., and R.M.R. Barclay. 2006 b. The benefits of living in a building: Big brown bats (Eptesicus fuscus) in rocks versus buildings. Journal of Mammalogy 87: 362-370.

Lausen, C.L., T.S. Jung, and J.M. Talerico. 2008. Range Extension of the Northern Longeared Bat (Myotis septentrionalis) in the Yukon. Northwestern Naturalist 89: 115-117.

Lippert, H.D. 2001. The relationship of bat activity to habitat type and structure retention in managed, Boreal forests of West-Central Alberta. MSc. thesis, Department of Renewable Resources, University of Alberta, Edmonton, AB.

Macdonald, S.E. 2006. Effects of partial postfire salvage harvesting on vegetation communities in the boreal mixedwood forest region of northeastern Alberta, Canada. Forest Ecology and Management 239: 21-31.

Marinelli, L. 2000. The use of residual patches by bats in the boreal forest of northwestern Alberta. In: Biodiversity in cutblocks with few large versus many small residual patches of trees and snags. (Schieck, J., S. Bradbury, S. Crites, L. Marinelli, T. Sorenson, C. Gray, D. McKinnon) Alberta Research Council. Vegreville. Pp. 122-131.

Martin, K.W., W.L. Puckette, S.L. Hensley, D.M. Leslie. 2000. Internal cave gating as a means of protecting cave dwelling bat populations in eastern Oklahoma. Proceedings of the Oklahoma Academia of Science 80: 133-137.

Menzel, M.A., S.F. Owen, W.M. Ford, J.W. Edwards, P.B. Wood, B.R. Chapman, and K.V. Miller. 2002. Roost tree selection by northern long-eared bat (Myotis septentrionalis) maternity colonies in an industrial forest of the central Appalachian mountains. Forest Ecology and Management 155: 107114.

Mills, R.S. 1971. A concentration of Myotis keenii at caves in Ohio. Journal of Mammalogy 52: 625.

Ministere de l'Environment et de la Faune. 1996. Protection program for bat hibernacula in Quebec. Quebec, PQ. $23 \mathrm{pp}$.

Mumford, R.E., and J.B. Cope. 1964. Distribution and status of the Chiroptera of Indiana. American Midland Naturalist 72: 473-489.

Nagorsen, D.W., and R.M. Brigham. 1993. Bats of British Columbia: Royal British Columbia museum handbook. University of British Columbia Press, Vancouver, BC. 164 pp.

Nagorsen D.W., and S.V. Nash. 1984. Distributional records of bats from the James Bay region. Canadian Field Naturalist 98: 500-502. 
National Research Council. 1995. Science and the Endangered Species Act. National Academy Press, Washington, DC. 271 pp.

NatureServe. 2008. NatureServe Explorer: an online encyclopedia of life [web application]. Version 7.0. Arlington, Virginia, USA: NatureServe. URL: http://www.natureserve.org/explorer [Updated: 1 February 2008; Accessed: 21 May 2008].

O'Shea, T.J., and M.A. Bogan. 2003. Introduction. In: Monitoring trends in bat populations of the United States and Territories: Problems and Prospects. (O'Shea, T.J. and M.A. Bogan, eds.) U.S. Geological Survey, Biological Resources Discipline, Information and Technology Report, pp. 1-7.

Owen, S.F., M.A. Menzel, W.M. Ford, B.R. Chapman, K.V. Miller, J.W. Edwards, and P.B. Wood. 2003. Home range size and habitat used by the northern myotis. American Midland Naturalist 150: 352-359.

Owen, S.F., M.A. Menzel, W.M. Ford, J.W. Edwards, B.R. Chapman, K.V. Miller, and P.B. Wood. 2002. Roost tree selection by maternal colonies of northern long-eared Myotis in an intensively managed forest. Gen. Tech. Rep. NE-292. Newtown Square, PA: U.S. Department of Agriculture, Forest Service, Northeastern Research Station. 6 pp.

Patriquin, K.J. 2001. Ecology of a bat community in harvested boreal forest in northwestern Alberta. M.Sc. thesis. University of Calgary, Calgary, Alberta.
Patriquin, K.J., and R.M.R. Barclay. 2003. Foraging by bats in cleared, thinned and unharvested boreal forest. Journal of Applied Ecology 40: 646-657.

Province of Alberta. 1991. Forest Management Agreement. Order of Council 556/91. Memorandum of Agreement between the Province of Alberta and Crestbrook Forest Industries Ltd., Edmonton; as cited in Cumming, S.G., P.J. Burton, S. Prahacs, and M.R. Garland. 1994. Potential conflicts between timber supply and habitat protection in the boreal mixedwood of Alberta, Canada: a simulation study. Forest Ecology and Management 68: 281-302.

Racey, P.A. 1973. Environmental factors affecting the length of gestation in heterothermic bats. Journal of Reproduction and Fertility, Supplemental 19: 175-189.

Racey, P.A. 1982. Ecology of bat reproduction. Pp 57-103 in Ecology of Bats (T. H. Kunz, ed.). Smithsonian Institution Press, Washington, DC. 425 pp.

Ratcliffe, J.M., and J.W. Dawson. 2003. Behavioural flexibility: the little brown bat, Myotis lucifugus, and the northern long-eared bat, M. septentrionalis, both glean and hawk prey. Animal Behaviour 66: 847-856

Rice, D.W. 1955. Myotis keenii in Florida. Journal of Mammalogy 36: 567.

Ricklefs, R.E. 1990. Ecology. W. H. Freeman and Company, New York.

Sasse, D.B., and P.J. Pekins. 1996. Summer roosting ecology of Northern LongEared Bats (Myotis septentrionalis) in the White Mountain National Forest. Pp. 91-101 in Bats and forests 
symposium (R.M.R. Barclay and R.M. Brigham, eds.). B. C. Ministry of Forests. Working Paper 23/1996, Victoria, BC. 292 pp.

Schowalter, D.B. 1979. Notes on the distribution of bats in Alberta and Saskatchewan. Blue Jay 37: 179-187.

Schowalter,D.B. 1980. Swarming,reproduction and early hibernation of Myotis lucifugus and M. volans in Alberta. Canada. Journal of Mammalogy 61: 350-354.

Smith, H.C. 1993. Alberta mammals, an atlas and guide. Provincial Museum of Alberta, Edmonton, AB. 238 pp.

Swanson, G., and C. Evans. 1936. The hibernation of certain bats in southern Minnesota. Journal of Mammalogy 17: 39-43.

Taylor, D.A.R. 1995. North American bats and mines project makes major progress. Bats 13: 3-4.

Taylor, D. 1996. Protecting bats in mines. Bats 14: 8-9.

Taylor, L.R. 1963. Temperature and insect flight. Journal of Animal Ecology 32: 99-117.

Thomas, D.W. 1993. Lack of evidence for a biological alarm clock in bats (Myotis spp.) hibernating under natural conditions. Canadian Journal of Zoology 71: 1-3.

Thomas, D.W. 1995. Hibernating bats are sensitive to non-tactile human disturbance. Journal of Mammalogy 76: $940-946$.
Thomas, D.W., M. Dorais, and J.M. Bergeron. 1990. Winter energy budgets and cost of arousals for hibernating Little Brown Bats, Myotis lucifugus. Journal of Mammal. 71: 475-479.

Turner, R.W. 1974. Mammals of the Black Hills of South Dakota and Wyoming. Univ. Kansas Museum Natural History Miscellaneous Publications. No. 60. Lawrence, Kansas. 178 pp.

Tuttle, M. 1996. Wisconsin gains key bat sanctuary. Bats 14: 3-7.

Tuttle, M.D., and D. Stevenson. 1982. Growth and survival of bats. Pp. 105150 in Ecology of Bats (T.H. Kunz ed.). Smithsonian Institution Press, Washington, DC. 425 pp.

U.S. Fish and Wildlife Service. 2008. The White-Nose Syndrome Mystery: Something is killing our bats. Northeast Region. URL: http://www. fws.gov/northeast/white_nose.html. [Accessed: 16 May 2008]).

van Mantgem, P.J., N.L. Stephenson, J.C. Byrne, L.D. Daniels, J.F. Franklin, P.Z. Fulé, M.E. Harmon, A.J. Larson, J.M. Smith, A.H. Taylor, and T.T. Veblen. 2009. Widespread increase of tree mortality rates in the Western United States. Science 323: 521-524.

van Zyll de Jong, C.G. 1979. Distribution and systematic relationships of long-eared Myotis in western Canada. Canadian Journal of Zoology 57: 987-994.

van Zyll de Jong, C.G. 1985. Handbook of Canadian mammals 2: Bats. National Museums of Canada, Ottawa, ON. 212 pp. 
van Zyll de Jong, C.G., M.B. Fenton, and J.G. Woods. 1980. Occurrence of Myotis californicus at Revelstoke and a second record of Myotis lucifugus for British Columbia. Canadian Field-Naturalist 94: 455-456.

Vonhof, M.J., and R.M.R. Barclay. 1996. Roost-site selection and roosting ecology of forest-dwelling bats in southern British Columbia. Canadian Journal of Zoology 74: 1797-1805.

Vonhof, M.J., and D. Hobson. 2001. Survey of the bats of central and northwestern Alberta. Alberta Sustainable Resource Development, Fish and Wildlife Service, Alberta Species at Risk Report No. 4. Edmonton, AB. 33 pp.

Vonhof, M.J., and L.C. Wilkinson. 1999. A summary of roosting requirements of northern long-eared myotis in northeastern British Columbia. Proceedings: Biology and Management of species and Habitats at Risk. Kamloops, B.C. 15-19 Feb. 1999: 459-460.

Vonhof, M.J., S. McNalley, and A. Yu. 1997. Roosting habitat requirements of northern long-eared bats (Myotis septentrionalis) in Northeastern British Columbia: the Fort Nelson River and Highway 77 area. Ministry of Environment, Lands and Parks, Fort St. John, B.C. 64 pp.

Vujnovic, D. 2001. Preliminary Mammalian Survey in the Area of Marguerite River Crag and Tail, Maybelle River and Richardson River Dunes Wildland
Provincial Parks, Alberta. Alberta Natural Heritage Information Centre, Parks and Protected Areas Division, Alberta Community Development, Edmonton, Alberta. 47 pp.

Walker, D., J.B. Stelfox, S. Wasel, and D. Hebert. 1996. Natural disturbance regimes as templates for boreal forest harvest. Bats and Forests Symposium, October 19-21, 1995, Victoria, British Columbia, Canada (R.M.R. Barclay and R.M. Brigham, eds.). Working Paper 23/1996, Research Branch, B.C. Ministry of Forests, Victoria, B.C. pp. $3-18$.

Wilde, C.J., C.H. Knight, and P.A. Racey. 1999. Influence of torpor on milk protein composition and secretion in lactating bats. Journal of Experimental Zoology 284: $35-41$.

Wilson, D.E., and D.M. Reeder (eds). 2005. Mammal Species of the World. A Taxonomic and Geographic Reference (3rd ed), Johns Hopkins University Press. 2142 pp.

Working Group on General Status of NWT Species. 2006. NWT Species 20062010 - General Status Ranks of Wild Species in the Northwest Territories, Department of Environment and Natural Resources, Government of the Northwest Territories, Yellowknife, NT. III pp.

Wrigley, R.E. 1974. Mammals of the sandhills of southwestern Manitoba. Canadian Field-Naturalist 88: 21-39. 
Appendix 1: Definitions of status ranks and legal designations.

A. The General Status of Alberta Wild Species 2005 (after Alberta Sustainable Resource Development 2007)

\begin{tabular}{|l|l|l|}
\hline 2005 Rank & 1996 Rank & Definitions \\
\hline At Risk & Red & $\begin{array}{l}\text { Any species known to be At Risk after formal detailed status } \\
\text { assessment and designation as Endangered or Threatened in } \\
\text { Alberta. }\end{array}$ \\
\hline May Be At Risk & Blue & $\begin{array}{l}\text { Any species that may be at risk of extinction or extirpation, and is } \\
\text { therefore a candidate for detailed risk assessment. }\end{array}$ \\
\hline Sensitive & Yellow & $\begin{array}{l}\text { Any species that is not at risk of extinction or extirpation but may } \\
\text { require special attention or protection to prevent it from becoming at } \\
\text { risk. }\end{array}$ \\
\hline Secure & Green & Any species that is not At Risk, May Be At Risk or Sensitive. \\
\hline Undetermined & $\begin{array}{l}\text { Status } \\
\text { Undetermined }\end{array}$ & $\begin{array}{l}\text { Any species for which insufficient information, knowledge or data } \\
\text { is available to reliably evaluate its general status. }\end{array}$ \\
\hline Not Assessed & $\mathrm{n} / \mathrm{a}$ & Any species that has not been examined during this exercise. \\
\hline Exotic/Alien & $\mathrm{n} / \mathrm{a}$ & Any species that has been introduced as a result of human activities. \\
\hline Extirpated/Extinct & $\mathrm{n} / \mathrm{a}$ & $\begin{array}{l}\text { Any species no longer thought to be present in Alberta (Extirpated) } \\
\text { or no longer believed to be present anywhere in the world (Extinct). }\end{array}$ \\
\hline Accidental/Vagrant & $\mathrm{n} / \mathrm{a}$ & $\begin{array}{l}\text { Any species occurring infrequently and unpredictably in Alberta, } \\
\text { i.e., outside its usual range. }\end{array}$ \\
\hline
\end{tabular}

\section{B. Alberta Species at Risk Formal Status Designations}

Species designated as Endangered under Alberta's Wildlife Act include those listed as Endangered or

Threatened in the Wildlife Regulation (in bold).

\begin{tabular}{|l|l|}
\hline Endangered & A species facing imminent extirpation or extinction. \\
\hline Threatened & A species likely to become endangered if limiting factors are not reversed. \\
\hline $\begin{array}{l}\text { Species of } \\
\text { Special Concern }\end{array}$ & $\begin{array}{l}\text { A species of special concern because of characteristics that make it particularly sensitive to } \\
\text { human activities or natural events. }\end{array}$ \\
\hline Data Deficient & A species for which there is insufficient scientific information to support status designation. \\
\hline
\end{tabular}

\section{Committee on the Status of Endangered Wildlife in Canada (after COSEWIC 2006)}

\begin{tabular}{|l|l|}
\hline Extinct & A species that no longer exists. \\
\hline Extirpated & A species that no longer exists in the wild in Canada, but occurs elsewhere. \\
\hline Endangered & A species facing imminent extirpation or extinction. \\
\hline Threatened & A species that is likely to become endangered if limiting factors are not reversed. \\
\hline Special Concern & $\begin{array}{l}\text { A species that may become threatened or endangered because of a combination of } \\
\text { biological characteristics and identified threats. }\end{array}$ \\
\hline Not at Risk & $\begin{array}{l}\text { A species that has been evaluated and found to be not at risk of extinction given the } \\
\text { current circumstances. }\end{array}$ \\
\hline Data Deficient & $\begin{array}{l}\text { A category that applies when the available information is insufficient to (a) resolve a } \\
\text { wildlife species' eligibility for assessment, or (b) permit an assessment of the wildlife } \\
\text { species' risk of extinction. }\end{array}$ \\
\hline
\end{tabular}


D. Heritage Status Ranks: Global (G), National (N), Sub-national (S) (after Alberta Natural Heritage Information Centre 2007, NatureServe 2008)

\begin{tabular}{|l|l|}
\hline G1/N1/S1 & $\begin{array}{l}5 \text { or fewer occurrences or only a few remaining individuals. May be especially vulnerable } \\
\text { to extirpation because of some factor of its biology. }\end{array}$ \\
\hline G2/N2/S2 & $\begin{array}{l}6 \text { to } 20 \text { or fewer occurrences or with many individuals in fewer locations. May be especially } \\
\text { vulnerable to extirpation because of some factor of its biology. }\end{array}$ \\
\hline G3/N3/S3 & $\begin{array}{l}21 \text { to } 100 \text { occurrences; may be rare and local throughout its range, or in a restricted range } \\
\text { (may be abundant in some locations). May be susceptible to extirpation because of large- } \\
\text { scale disturbances. }\end{array}$ \\
\hline G4/N4/S4 & Typically $>100$ occurrences. Apparently secure. \\
\hline G5/N5/S5 & Typically $>100$ occurrences. Demonstrably secure. \\
\hline GX/NX/SX & Believed to be extinct or extirpated; historical records only. \\
\hline GH/NH/SH & Historically known; may be relocated in the future. \\
\hline G?/N?/S? & Not yet ranked, or rank tentatively assigned. \\
\hline
\end{tabular}

E. United States Endangered Species Act (after National Research Council 1995)

\begin{tabular}{|l|l|}
\hline Endangered & Any species that is in danger of extinction throughout all or a significant portion of its range. \\
\hline Threatened & $\begin{array}{l}\text { Any species that is likely to become an endangered species within the foreseeable future } \\
\text { throughout all or a significant portion of its range. }\end{array}$ \\
\hline
\end{tabular}


Appendix 2. Site locations of the northern myotis in Alberta. Map numbers refer to points in Figure 1. Non-published data were obtained from Fish and Wildlife Management Information System, Alberta Sustainable Resource Development (May 15, 2008 for data Z1997, and Jan. 26, 2009 for data $<1997$ ).

\begin{tabular}{|c|c|c|c|c|}
\hline MAP \# & LOCATION & SOURCE/MUSEUM RECORD NUMBER & $\begin{array}{c}\text { Latitude } \\
\left({ }^{0} \mathbf{N}\right)\end{array}$ & $\begin{array}{c}\text { Longitude } \\
\left({ }^{\circ} \mathrm{W}\right)\end{array}$ \\
\hline 1 & Cadomin Cave area & $\begin{array}{l}\text { H. Smith (pers. comm.), M. Pybus (pers. comm.): } \\
9 \text { bats banded and released (1976 - 1979); } \\
\text { Provincial Museum of Alberta }\left(\text { PMA }^{1}\right) \text {-- } \\
\text { Z77.62.5/ Z78.83.5/ Z78.83.6/Z78.84.1/Z78.88.1/ } \\
\text { Z78.88.2/ Z79.110.1/ Z79.110.2/ Z79.116.1/ } \\
\text { Z79.116.2/ Z79.116.3/ Z79.116.4/ Z79.116.5/ } \\
\text { Z79.116.6/ Z79.116.7/ Z79.116.8 }\end{array}$ & 53.00 & -117.33 \\
\hline 2 & Hinton & $\begin{array}{l}\text { M. Pybus (pers. comm., } 1 \text { bat banded and } \\
\text { released in 1990) }\end{array}$ & 53.67 & -118.00 \\
\hline 3 & Edson & $\begin{array}{l}\text { M. Pybus (pers. comm., } 3 \text { bats banded and } \\
\text { released in 1991); PMA -- } 83.23 .9\end{array}$ & 53.58 & -116.43 \\
\hline 4 & Edson area & $\begin{array}{l}\text { University of Alberta Museum of Zoology }{ }^{2} \text { field } \\
\text { No. } 160 \text { (date not available) }\end{array}$ & 53.58 & -116.42 \\
\hline 5 & Lesser Slave Lake & PMA / 83.23.8 (1981) & 55.50 & -115.68 \\
\hline 6 & Drayton Valley & PMA / Z81.20.1 (1980); Lippert (2001) & 53.00 & -115.00 \\
\hline 7 & Spruce Grove & PMA / Z76.101.1 (1976) & 53.55 & -113.90 \\
\hline 8 & Edmonton & $\begin{array}{l}\text { PMA -- Z76.123.1/Z78.69.1/Z79.87.1/83.23.7 } \\
(1976 \text { - 1981) }\end{array}$ & 53.53 & -113.53 \\
\hline 9 & $\begin{array}{l}\text { Elk Island National } \\
\text { Park }\end{array}$ & Holroyd (1983); Vonhof and Hobson (2001) & 53.62 & -112.87 \\
\hline 10 & Lac La Biche area & Crampton (1995) & 54.50 & -112.00 \\
\hline 11 & Fort MacKay area & PMA / 83.22.1 (1983) & 57.17 & -111.62 \\
\hline 12 & Fort MacKay area & $\begin{array}{l}\text { Birch Mountain Resources Muskeg Valley } \\
\text { Quarry Project EIA, 2004, C. Godwin-Sheppard, } \\
\text { pers. comm.; Albian Sands Energy Inc. Muskeg } \\
\text { River Mine Expansion Project, 2005, S. Grindal, } \\
\text { pers. comm.; Hubbs and Schowalter (2003); Deer } \\
\text { Creek Energy Ltd. Environmental Impact } \\
\text { Assessment 2005, C. Godwin-Sheppard, pers. } \\
\text { comm. }\end{array}$ & 57.17 & -111.54 \\
\hline 13 & Fort MacKay area & $\begin{array}{l}\text { Petro-Canada MacKay River Environmental } \\
\text { Impact Assessment, 2005, C. Godwin-Sheppard, } \\
\text { pers. comm. }\end{array}$ & 57.07 & -111.92 \\
\hline 14 & Fort MacKay area & $\begin{array}{l}\text { Environmental Impact Assessment for the Heavy } \\
\text { Oil Lease Area, North of Fort McMurray, 2006, } \\
\text { C. Godwin-Sheppard, pers. comm. }\end{array}$ & 57.31 & -110.50 \\
\hline 15 & NE of Ft. MacKay & $\begin{array}{l}\text { Environmental Impact Assessment for the Heavy } \\
\text { Oil Lease Area, North of Fort McMurray, 2006, } \\
\text { B. Hamilton, pers. comm. }\end{array}$ & 57.56 & -110.70 \\
\hline 16 & Peace River & PMA / Z77.144.1 (1977) & 56.22 & -117.27 \\
\hline
\end{tabular}


Appendix 2 continued:

\begin{tabular}{|c|c|c|c|c|}
\hline MAP \# & LOCATION & SOURCE/MUSEUM RECORD NUMBER & $\begin{array}{c}\text { Latitude } \\
\left({ }^{\circ} \mathbf{N}\right)\end{array}$ & $\begin{array}{c}\text { Longitude } \\
\left({ }^{\circ} \mathbf{W}\right)\end{array}$ \\
\hline 17 & $\begin{array}{l}\sim 70 \mathrm{~km} \mathrm{NW} \text { of Peace } \\
\text { River }\end{array}$ & Patriquin (2001) & 56.67 & -118.00 \\
\hline 18 & Grande Prairie & PMA / Z78.123.1 (1978); Lippert (2001) & 55.00 & -119.00 \\
\hline 19 & Spirit River & PMA / 83.23.6 (1981) & 55.78 & -118.83 \\
\hline 20 & High Level & PMA / Z75.106.1 (1975) & 58.52 & -117.08 \\
\hline 21 & $\begin{array}{l}\text { Wood Buffalo } \\
\text { National Park }\end{array}$ & $\begin{array}{l}\text { National Museum of Canada } 243405 \text { (date not } \\
\text { available) }\end{array}$ & 59.78 & -112.32 \\
\hline 22 & $\begin{array}{l}\text { Wood Buffalo } \\
\text { National Park }\end{array}$ & PMA -- Z78.49.2 (1978) & 59.67 & -112.32 \\
\hline 23 & Wabasca River & Vonhof and Hobson (2001) & 57.79 & -115.34 \\
\hline 24 & Rainbow Lake & Vonhof and Hobson (2001) & 58.30 & -119.29 \\
\hline 25 & Sousa Creek & Vonhof and Hobson (2001) & 58.68 & -118.68 \\
\hline 26 & Conklin area & Hubbs and Schowalter (2003) & 55.66 & -111.14 \\
\hline 27 & Conklin area & $\begin{array}{l}\text { StatOil Baseline Survey, 2008, Matrix Solutions, } \\
\text { D. Player, pers. comm. }\end{array}$ & 55.81 & -111.33 \\
\hline 28 & Fort McMurray area & $\begin{array}{l}\text { AOSC Baseline Survey, 2008, Matrix Solutions, } \\
\text { D. Player, pers. comm. }\end{array}$ & 56.69 & -111.98 \\
\hline 29 & Fort McMurray area & $\begin{array}{l}\text { Nexen Baseline Survey, 2008, Matrix Solutions, } \\
\text { D. Player, pers. comm. }\end{array}$ & 56.41 & -110.86 \\
\hline 30 & $\begin{array}{l}\text { Athabasca Tar Sands } \\
\text { area }\end{array}$ & $\begin{array}{l}\text { Suncor Voyageur Baseline Survey, 2004, Golder } \\
\text { Associates, N. McDonald, pers. comm. }\end{array}$ & 56.95 & -111.51 \\
\hline 31 & $\begin{array}{l}\text { Cooking Lake } \\
\text { Blackfoot Provincial } \\
\text { Park }\end{array}$ & Vonhof and Hobson (2001) & 53.46 & -112.81 \\
\hline 32 & $\begin{array}{l}\text { Content Bridge, Red } \\
\text { Deer River }\end{array}$ & Lausen (2006a) & 52.31 & -113.08 \\
\hline 33 & C.F.B. Wainright & $\begin{array}{l}\text { C. Lausen and L. Burt, pers. comm. (2008 } \\
\text { baseline survey by Westworth Associates) }\end{array}$ & 52.75 & -111.17 \\
\hline
\end{tabular}

\footnotetext{
${ }^{1}$ Provincial Museum of Alberta

${ }^{2}$ University of Alberta Museum of Zoology and National Museum of Canada data from van Zyll de Jong (1979).
} 


\section{List of Titles in This Series}

(as of May 2009)

No. 1 Status of the Piping Plover (Charadrius melodus) in Alberta, by David R. C. Prescott. 19 pp. (1997)

No. 2 Status of the Wolverine (Gulo gulo) in Alberta, by Stephen Petersen. 17 pp. (1997)

No. 3 Status of the Northern Long-eared Bat (Myotis septentrionalis) in Alberta, by M. Carolina Caceres and M. J. Pybus. 19 pp. (1997)

No. 3 Update 2009. Status of the Northern Myotis (Myotis septentrionalis) in Alberta. Alberta Sustainable Resource Development and Alberta Conservation Association. 34 pp. (2009)

No. 4 Status of the Ord's Kangaroo Rat (Dipodomys ordii) in Alberta, by David L. Gummer. 16 pp. (1997)

No. 5 Status of the Eastern Short-horned Lizard (Phrynosoma douglassii brevirostre) in Alberta, by Janice D. James, Anthony P. Russell and G. Lawrence Powell. 20 pp. (1997)

No. 5 Update 2004. Status of the Short-horned Lizard (Phrynosoma hernandesi) in Alberta. Alberta Sustainable Resource Development. 27 pp. (2004)

No. 6 Status of the Prairie Rattlesnake (Crotalus viridis viridis) in Alberta, by Sheri M. Watson and Anthony P. Russell. 26 pp. (1997)

No. 7 Status of the Swift Fox (Vulpes velox) in Alberta, by Susan E. Cotterill. 17 pp. (1997)

No. 8 Status of the Peregrine Falcon (Falco peregrinus anatum) in Alberta, by Petra Rowell and David P. Stepnisky. 23 pp. (1997)

No. 9 Status of the Northern Leopard Frog (Rana pipiens) in Alberta, by Greg Wagner. 46 pp. (1997)

No. 9 Update 2003. Status of the Northern Leopard Frog (Rana pipiens) in Alberta. Alberta Sustainable Resource Development. 61 pp. (2003)

No. 10 Status of the Sprague's Pipit (Anthus spragueii) in Alberta, by David R. C. Prescott. 14 pp. (1997)

No. 11 Status of the Burrowing Owl (Speotyto cunicularia hypugaea) in Alberta, by Troy I. Wellicome. $21 \mathrm{pp}$. (1997)

No. 11 Update 2005. Status of the Burrowing Owl (Athene cunicularia) in Alberta. Alberta Sustainable Resource Development and Alberta Conservation Association. 28 pp. (2005)

No. 12 Status of the Canadian Toad (Bufo hemiophrys) in Alberta, by Ian M. Hamilton, Joann L. Skilnick, Howard Troughton, Anthony P. Russell, and G. Lawrence Powell. 30 pp. (1998)

No. 13 Status of the Sage Grouse (Centrocercus urophasianus urophasianus) in Alberta, by Cameron L. Aldridge. 23 pp. (1998)

No. 14 Status of the Great Plains Toad (Bufo cognatus) in Alberta, by Janice D. James. 26 pp. (1998)

No. 15 Status of the Plains Hognose Snake (Heterodon nasicus nasicus) in Alberta, by Jonathan Wright and Andrew Didiuk. 26 pp. (1998)

No. 16 Status of the Long-billed Curlew (Numenius americanus) in Alberta, by Dorothy P. Hill. 20 pp. (1998) 
No. 17 Status of the Columbia Spotted Frog (Rana luteiventris) in Alberta, by Janice D. James. 21 pp. (1998)

No. 18 Status of the Ferruginous Hawk (Buteo regalis) in Alberta, by Josef K. Schmutz. 18 pp. (1999)

No. 18 Update 2006. Status of the Ferruginous Hawk (Buteo regalis) in Alberta. Alberta Sustainable Resource Development and Alberta Conservation Association. 22 pp. (2006)

No. 19 Status of the Red-tailed Chipmunk (Tamias ruficaudus) in Alberta, by Ron Bennett. 15 pp. (1999)

No. 20 Status of the Northern Pygmy Owl (Glaucidium gnoma californicum) in Alberta, by Kevin C. Hannah. 20 pp. (1999)

No. 21 Status of the Western Blue Flag (Iris missouriensis) in Alberta, by Joyce Gould. 22 pp. (1999)

No. 21 Update 2005. Status of the Western Blue Flag (Iris missouriensis) in Alberta. Alberta Sustainable Resource Development and Alberta Conservation Association. 29 pp. (2005)

No. 22 Status of the Long-toed Salamander (Ambystoma macrodactylum) in Alberta, by Karen L. Graham and G. Lawrence Powell. 19 pp. (1999)

No. 23 Status of the Black-throated Green Warbler (Dendroica virens) in Alberta, by Michael R. Norton. 24 pp. (1999)

No. 24 Status of the Loggerhead Shrike (Lanius ludovicianus) in Alberta, by David R. C. Prescott and Ronald R. Bjorge. 28 pp. (1999)

No. 25 Status of the Plains Spadefoot (Spea bombifrons) in Alberta, by Richard D. Lauzon. 17 pp. (1999)

No. 26 Status of the Trumpeter Swan (Cygnus buccinator) in Alberta, by M. Lynne James. 21 pp. (2000)

No. 27 Status of the Pygmy Whitefish (Prosopium coulteri) in Alberta, by William C. Mackay. 16 pp. (2000)

No. 28 Status of the Short-eared Owl (Asio flammeus) in Alberta, by Kort M. Clayton. 15 pp. (2000)

No. 29 Status of the Willow Flycatcher (Empidonax traillii) in Alberta, by Bryan Kulba and W. Bruce McGillivray. 15 pp. (2001)

No. 30 Status of the Woodland Caribou (Rangifer tarandus caribou) in Alberta, by Elston Dzus. 47 pp. (2001)

No. 31 Status of the Western Spiderwort (Tradescantia occidentalis) in Alberta, by Bonnie Smith. 12 pp. (2001)

No. 32 Status of the Bay-breasted Warbler (Dendroica castanea) in Alberta, by Michael Norton. 21 pp. (2001)

No. 33 Status of the Cape May Warbler (Dendroica tigrina) in Alberta, by Michael Norton. 20 pp. (2001)

No. 34 Status of the Whooping Crane (Grus americana) in Alberta, by Jennifer L. White. 21 pp. (2001)

No. 35 Status of Soapweed (Yucca glauca) in Alberta, by Donna Hurlburt. 18 pp. (2001)

No. 36 Status of the Harlequin Duck (Histrionicus histrionicus) in Alberta, by Beth MacCallum. 38 pp. (2001)

No. 37 Status of the Grizzly Bear (Ursus arctos) in Alberta, by John L. Kansas. 43 pp. (2002)

No. 38 Status of the Wood Bison (Bison bison athabascae) in Alberta, by Jonathan A. Mitchell and C. Cormack Gates. 32 pp. (2002) 
No. 39 Status of the Bull Trout (Salvelinus confluentus) in Alberta, by John R. Post and Fiona D. Johnston. 40 pp. (2002)

No. 40 Status of the Banff Springs Snail (Physella johnsoni) in Alberta, by Dwayne A.W. Lepitzki. 29 pp. (2002)

No. 41 Status of the Shortjaw Cisco (Coregomus zenithicus) in Alberta, by Mark Steinhilber. 23 pp. (2002)

No. 42 Status of the Prairie Falcon (Falco mexicanus) in Alberta, by Dale Paton. 28 pp. (2002)

No. 43 Status of the American Badger (Taxidea taxus) in Alberta, by Dave Scobie. 17 pp. (2002)

No. 44 Status of the Yucca Moth (Tegeticula yuccasella) in Alberta. Alberta Sustainable Resource Development. 21 pp. (2002)

No. 45 Status of the White-winged Scoter (Melanitta fusca deglandi) in Alberta. Alberta Sustainable Resource Development. 15 pp. (2002)

No. 46 Status of the Lake Sturgeon (Acipenser fulvescens) in Alberta. Alberta Sustainable Resource Development. 30 pp. (2002)

No. 47 Status of the Western Silvery Minnow (Hybognathus argyritis) in Alberta. Alberta Sustainable Resource Development. 24 pp. (2003)

No. 48 Status of the Small-flowered Sand Verbena (Tripterocalyx micranthus) in Alberta. Alberta Sustainable Resource Development. 24 pp. (2003)

No. 49 Status of the Brown Creeper (Certhia americana) in Alberta. Alberta Sustainable Resource Development. 30 pp. (2003)

No. 50 Status of the Mountain Plover (Charadrius montanus) in Alberta. Alberta Sustainable Resource Development. 25 pp. (2003)

No. 51 Status of the St. Mary Shorthead Sculpin (provisionally Cottus bairdi punctulatus) in Alberta. Alberta Sustainable Resource Development. 24 pp. (2003)

No. 52 Status of the Stonecat (Noturus flavus) in Alberta. Alberta Sustainable Resource Development. 22 pp. (2003)

No. 53 Status of the Sage Thrasher (Oreoscoptes montanus) in Alberta. Alberta Sustainable Resource Development. 23 pp. (2004)

No. 54 Status of the Tiny Cryptanthe (Cryptantha minima) in Alberta. Alberta Sustainable Resource Development. 39 pp. (2004)

No. 55 Status of the Slender Mouse-ear-cress (Halimolobos virgata) in Alberta. Alberta Sustainable Resource Development. 27 pp. (2005)

No. 56 Status of the Barred Owl (Strix varia) in Alberta. Alberta Sustainable Resource Development. 15 pp. (2005)

No. 57 Status of the Arctic Grayling (Thymallus arcticus) in Alberta. Alberta Sustainable Resource Development. 41 pp. (2005)

No. 58 Status of the Weidemeyer's Admiral (Limenitis weidemeyerii) in Alberta. Alberta Sustainable Resource Development and Alberta Conservation Association. 13 pp. (2005) 
No. 59 Status of the Porsild's Bryum (Bryum porsildii) in Alberta. Alberta Sustainable Resource Development and Alberta Conservation Association. 30 pp. (2006)

No. 60 Status of the Western Grebe (Aechmophorus occidentalis) in Alberta. Alberta Sustainable Resource Development and Alberta Conservation Association. 29 pp. (2006)

No. 61 Status of the Westslope Cutthroat Trout (Oncorhynchus clarkii lewisii) in Alberta. Alberta Sustainable Resource Development and Alberta Conservation Association. 34 pp. (2006)

No. 62 Status of the Limber Pine (Pinus flexilis) in Alberta. Alberta Sustainable Resource Development and Alberta Conservation Association. 17 pp. (2007)

No. 63 Status of the Whitebark Pine (Pinus albicaulis) in Alberta. Alberta Sustainable Resource Development and Alberta Conservation Association. 22 pp. (2007)

No. 64 Status of the Western Small-footed Bat (Myotis ciliolabrum) in Alberta. Alberta Sustainable Resource Development and Alberta Conservation Association. 24 pp. (2008)

No. 65 Status of the Verna's Flower Moth (Schinia verna) in Alberta. Alberta Sustainable Resource Development and Alberta Conservation Association. 17 pp. (2008) 





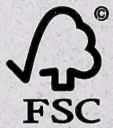
FSC

Mixed Sources Product group from well-managed recycled wood or fibre
rest, controled sources and

Cert no. SW-COC-003027 Www.fsc.org
1996 forest Stewardship Council 